\title{
A Model of Shadow Banking
}

\section{Citation}

Gennaioli, Nicola, Andrei Shleifer, And Robert W. Vishny. 2013. "A Model of Shadow Banking."

The Journal of Finance 68 (4) (August 16): 1331-1363. doi:10.1111/jofi.12031. http:// dx.doi.org/10.1111/jofi.12031.

\section{Published Version}

doi:10.1111/jofi.12031

\section{Permanent link}

http://nrs.harvard.edu/urn-3:HUL.InstRepos:11688792

\section{Terms of Use}

This article was downloaded from Harvard University's DASH repository, and is made available under the terms and conditions applicable to Open Access Policy Articles, as set forth at http:// nrs.harvard.edu/urn-3:HUL.InstRepos:dash.current.terms-of-use\#OAP

\section{Share Your Story}

The Harvard community has made this article openly available.

Please share how this access benefits you. Submit a story.

Accessibility 


\title{
A Model of Shadow Banking
}

\author{
NICOLA GENNAIOLI, ANDREI SHLEIFER, AND ROBERT W. VISHNY*
}

\begin{abstract}
We present a model of shadow banking in which banks originate and trade loans, assemble them into diversified portfolios, and finance these portfolios externally with riskless debt. In this model: outside investor wealth drives the demand for riskless debt and indirectly for securitization, bank assets and leverage move together, banks become interconnected through markets, and banks increase their exposure to systematic risk as they reduce idiosyncratic risk through diversification. The shadow banking system is stable and welfare improving under rational expectations, but vulnerable to crises and liquidity dry-ups when investors ignore tail risks.
\end{abstract}

\footnotetext{
* Università Bocconi, Harvard University, and University of Chicago, respectively. We are grateful to Viral Acharya, Tobias Adrian, Efraim Benmelech, John Campbell, Robin Greenwood, Samuel Hanson, Arvind Krishnamurthy, Raghu Rajan, Rafael Repullo, Matthew Richardson, Philipp Schnabl, Joshua Schwartzstein, Alp Simsek, Jeremy Stein, Rene Stulz, Amir Sufi, the Editor, Campbell Harvey, and two anonymous referees, and especially Charles-Henri Weymuller for helpful comments. Gennaioli thanks the Barcelona Graduate School of Economics and the European Research Council for financial support.
} 
Shadow banking typically describes financial activities occurring outside the regulated banking sector. In recent years, the most important such activities took the form of rapidly expanding provision of short term safe debt to financial intermediaries through money market funds and other sources outside of the regulated banking sector (Coval, Jurek, and Stafford (2009a), Gorton and Metrick (2010, 2012), Poszar et al. (2010), Shin (2009)). Much of that debt was collateralized through the process called securitization, which involves origination and acquisition of loans by financial intermediaries, the assembly of these loans into diversified pools, and the tranching of the pools to manufacture safe pieces. While regulated banks played a key role in securitization and held large amounts of securitized assets, a large share of the ultimate financing of securitized assets was provided by the shadow banking system. The collapse of shadow banking in 2007 to 2008 arguably played a critical role in undermining the regulated banking sector, and in bringing about the financial crisis.

In this paper, we present a new model of shadow banking and securitization. In the model, a financial intermediary can originate or acquire both safe and risky loans, and can finance these loans from its own resources as well as by issuing debt. The risky loans are subject to both institution-specific idiosyncratic risk and aggregate risk. Critically, but in line with actual experience (e.g., Bernanke et al. (2011)), outside investors are only interested in riskless debt (they are assumed to be infinitely risk-averse). When outside investors' wealth is limited, demand for riskless debt is low, so intermediaries' own wealth and returns from safe projects are sufficient to guarantee whatever riskless debt they issue. At higher levels of investor wealth and demand for riskless debt, however, intermediaries cannot generate enough collateral with safe projects, and an intermediary's own risky projects cannot serve as useful collateral for riskless debt because they are vulnerable to 
idiosyncratic risk. To meet the demand for riskless debt, intermediaries diversify their portfolios by buying and selling risky loans to eliminate idiosyncratic risk, similarly to Diamond (1984). Their assets in the form of loan portfolios, and their liabilities in the form of riskless debt issued to finance these portfolios, grow together. Intermediaries essentially pursue a carry trade, whereby they pledge the returns on their loan portfolio in the worst aggregate state of the world as collateral for riskless debt and earn the upside in better states of the world.

As intermediaries expand their balance sheets by buying risky projects, they increase the systematic risk of their portfolios, raise their leverage, and endogenously become interconnected by sharing each other's risks. This is our critical new result: the very diversification that eliminates intermediary-specific risks by pooling loans so as to support the issuance of debt perceived to be riskless actually raises intermediaries' exposure to tail aggregate risks. Still, under rational expectations, riskless debt is always repaid, and the system is very stable. The expansion of activity financed by the shadow banking system is Pareto-improving, as in standard models of risk sharing (Ross (1976), Allen and Gale (1994)).

Things change dramatically when investors and intermediaries neglect tail risks, perhaps because they do not think about truly bad outcomes during quiet times. Gennaioli, Shleifer, and Vishny (GSV 2012) argue that the neglect of tail risk is critical to understanding aspects of the crisis. There is growing evidence that prior to the crisis even sophisticated investors did not appreciate the possibility of sharp declines in housing prices (Gerardi et al. (2008)), and did not have accurate models for pricing securitized debt, particularly Collateralized Debt Obligations (Jarrow et al. (2007), Coval, Jurek, and Stafford 
(2009a)). GSV show that, with neglected risk, new financial products provide false substitutes for truly safe bonds, and as a consequence can reduce welfare.

In this paper, we further develop this argument by focusing more explicitly on how the shadow banking system offers insurance to investors. We model not only aggregate but also idiosyncratic risk. By enabling the diversification of idiosyncratic risk, securitization promotes the expansion of bank balance sheets and increases financial links among banks. Through these channels, the insurance against idiosyncratic risk interacts with the neglect of tail aggregate risks in creating extreme financial fragility. Brown (2010) refers to this phenomenon as "the diversification myth."

In the range of parameter values corresponding to extensive securitization, investors neglecting downside risks believe that the payoffs on the collateral in the worst case scenario are higher than they actually are, and buy more debt thinking that it is riskless. The balance sheets of intermediaries expand further than they would under rational expectations. However, as intermediaries pool loans to support debt issuance, they increase their exposure to systematic risk. When they and investors realize that a worse state of the world than they had previously contemplated might occur, intermediaries face massive exposure to that downside risk, which they bear because they sold "riskless" bonds to investors. At this point, systematic risk becomes systemic in the sense that exposure to macroeconomic risk causes all intermediaries to fail together. While harmless when market participants recognize all risks, the diversification myth becomes deadly when they do not.

Section I presents our model of shadow banking. Section II solves the model under rational expectations, and shows how shadow banking improves intertemporal trade, insurance opportunities, and welfare. In Section III, we solve the model under the 
assumption of neglected risks, and show how false insurance provided by financial intermediaries when risks are ignored can misallocate risks. The very benefits of shadow banking obtained through diversification and leverage become the source of its demise. In Section IV, we add the opportunities for interim trading to the model, and examine the evolution of liquidity under neglected risks. We also briefly examine the role of short term debt. In Section $\mathrm{V}$ we compare our model to the two leading theories of securitization, adverse selection and regulatory arbitrage. Section VI concludes. All proofs are collected in an Internet Appendix. ${ }^{1}$

\section{The Model}

We build on the production model of GSV (2012), with three dates $t=0,1,2$ and a measure one of investors who at $t=0$ receive a perishable endowment $w$ and enjoy utility

$$
\mathrm{U}=\mathrm{E}_{\omega}\left[C_{0}+\min _{\omega \in \Omega_{1}} C_{1, \omega}+\min _{\omega \in \Omega_{2}} C_{2, \omega}\right]
$$

where $C_{t, \omega}$ is consumption at $t=1,2$ in state of nature $\omega \in \Omega_{t}$. Investors are infinitely riskaverse in the sense that they value future consumption levels at their worst-case scenario. ${ }^{2}$

Investors save by buying financial claims from a measure one of risk-neutral intermediaries, who are indifferent between consuming at $t=0,1,2$. Intermediaries receive an endowment $w_{\text {int }}<1$ at $t=0$, and use it - along with the funds raised from investors - to finance two activities $\mathrm{H}$ and $\mathrm{L}$. Activity $\mathrm{H}$ is riskless: by investing at $t=0$ an amount $I_{\mathrm{H}, j}$ in $\mathrm{H}$, at $t=2$ intermediary $j$ obtains the sure amount $R \cdot I_{\mathrm{H}, j}$. Activity $\mathrm{L}$ is risky: by investing at $t$ $=0$ an amount $I_{\mathrm{L}, j}$ in $\mathrm{L}$, at $t=2$ intermediary $j$ obtains the amount 


$$
f\left(I_{L, j}\right)=\left\{\begin{array}{cccc}
A I_{L, j} & \text { with probability } \pi_{\omega} \\
0 & \text { with probability } 1-\pi_{\omega}
\end{array}\right.
$$

in state $\omega \in \Omega_{2}$. The return on the risky activity is i.i.d. across intermediaries, and $\pi_{\omega}$ captures the share of investments that "succeed" in $\omega$. There are three final states $\Omega_{2} \equiv\{g, d, r\}$ such that $\pi_{g}>\pi_{d}>\pi_{r}$. Here $g$ captures a "growth" state in which most investments succeed, $d$ a less productive "downturn," and $r$ an even less productive "recession." At $t=0$ it is known that state $\omega \in \Omega_{2}$ occurs with probability $\varphi_{\omega}>0$, where $\sum_{\omega} \varphi_{\omega}=1$. Unlike in GSV (2012), here intermediaries are subject to idiosyncratic, and not only aggregate, risk.

The expected return of $\mathrm{H}$ is not smaller than that of $\mathrm{L}, \mathrm{R} \geq \mathrm{E}_{\omega}\left(\pi_{\omega}\right) \cdot A$, so that intermediaries (weakly) prefer to invest in the safe activity to investing in the risky one. Riskless projects, however, are in limited unit supply, $\int_{j} I_{\mathrm{H}, j} \mathrm{~d} j \leq 1$, and there are no "storage" opportunities. To expand investment beyond this limit, intermediaries must undertake lowerreturn risky projects. We can view investment projects in this model as mortgages, with riskier mortgages also offering lower expected returns. ${ }^{3} \quad$ Figure 1 shows the decreasing marginal return on investment in the economy. Low return projects are riskier, both in the aggregate and at the level of the intermediary (the dashed lines capture the possible realizations of returns at the level of an intermediary).

\section{[Figure 1 here]}

In a given aggregate state of the world, each intermediary faces an idiosyncratic risk on its projects (mortgages), perhaps because it is costly to fully diversify its investments. The intermediary can diversify its idiosyncratic (but not aggregate) risk by buying the projects 
issued by other intermediaries. We thus assume that an intermediary cannot diversify all idiosyncratic risk through its own projects; it must buy those of others. The available evidence on asset-backed commercial paper conduits indeed shows that such vehicles held a variety of securities of different kinds from different countries (Acharya and Schnabl (2010)). Since the intermediary is risk-neutral, however, it does not value diversification per se.

Intermediaries raise funds in two ways. First, they issue riskless debt claims promising a sure return $r \geq 1$ at $t=2$. Riskless debt is a senior security that pledges the lowest realization of the payoff on an intermediary's total assets. Because this debt is senior, it is the last security to absorb losses, if any. Our focus on riskless debt captures investor demand for AAA-rated securities driven by regulation, taste for characteristics, and risk aversion.

The second way for intermediaries to raise funds is to "securitize" their projects (mortgages), which here refers to selling them at $t=0$ in exchange for cash. The price received by an intermediary for selling one unit of investment at $t=0$ is equal to $p_{\mathrm{H}}$ for a riskless project $\mathrm{H}$ and to $p_{\mathrm{L}}$ for a risky project L. Intermediaries can also trade projects among themselves, which as we show below boosts their debt capacity. In our model debt and securitization are complements, as the bank puts together a diversified portfolio of projects, tranches it, and pledges the safe portion of returns to raise riskless debt. Diversification allows the creation of AAA-rated collateral to raise AAA-rated debt. For now we only consider safe cash flows as collateral; we allow intermediaries to back debt with risky collateral in Section IV.B.

The timing of the model works as follows. At $t=0$, the return on risky projects is not known and each intermediary $j$ : i) raises $D_{j}$ units of riskless debt promising to repay $r D_{j}$ at $t=$ 2 (the intermediary lends if $D_{j}<0$ ), and ii) sells $S_{\mathrm{H}, j}$ and $S_{\mathrm{L}, j}$ units of riskless and risky projects, respectively. Using its own wealth $w_{\text {int }}$ and the resources raised, the intermediary: i) 
invests $I_{\mathrm{H}, j}$ and $I_{\mathrm{L}, j}$ units in the riskless and risky projects of its own, respectively, and ii) buys $T_{\mathrm{H}, j}$ and $T_{\mathrm{L}, j}$ units, respectively, of riskless and risky projects financed by other intermediaries. Each investor $i$ chooses how much riskless debt $D_{i}$ to issue (the investor lends if $D_{i}<0$ ) and how many securitized projects $T_{\mathrm{H}, i}$ and $T_{\mathrm{L}, i}$ to buy. (In equilibrium, investors will buy riskless debt and not trade in projects, but at the moment we keep the framework general.) Markets for debt and for securitized projects clear at competitive prices $r, p_{\mathrm{H}}$, and $p_{\mathrm{L}}$.

At $t=1$, intermediaries can raise new funds, securitized projects can be re-traded, and investors can re-optimize their consumption decisions. At $t=2$, output from projects is produced and distributed to intermediaries and investors. The world ends.

Crucially, at $t=1$ everyone learns the return on intermediaries' risky projects and the aggregate state $\omega$. Formally, in equation (1) we have $\Omega_{1}=\Omega_{2}=\{g, d, r\}$. As a consequence, at $t=1$ all market participants share the same preferences and the same reservation prices over assets. Thus, markets at $t=1$ play no role. We can view this model as consisting only of two dates, $t=0$ and $t=2$. In the extension of Section IV, the $t=1$ market plays a key role.

We simplify the equilibrium analysis by making the following assumption.

ASSUMPTION 1: $\pi_{d} \cdot A<1$,

which implies that under both rational expectations and local thinking, intermediaries can only borrow a limited amount of funds. Our main results do not rely on this assumption. We examine the joint determination of leverage and securitization, as well as the forms of securitization, by first assuming rational expectations and then turning to neglected risks.

\section{Equilibrium Under Rational Expectations}

If an intermediary $j$ adopts a borrowing, investment, and securitization policy $\left(D_{j}, I_{\mathrm{H}_{j}, j}\right.$, 
$\left.I_{\mathrm{L}, j}, S_{\mathrm{H}, j}, S_{\mathrm{L}, j}, T_{\mathrm{H}, j}, T_{\mathrm{L}, j}\right)$ at $t=0$, its expected profit is the following sum of three components:

$$
\begin{aligned}
& {\left[R \cdot\left(I_{\mathrm{H}, j}+T_{\mathrm{H}, j}-S_{\mathrm{H}, j}\right)+p_{\mathrm{H}}\left(S_{\mathrm{H}, j}-T_{\mathrm{H}, j}\right)\right]+} \\
& +\left[\mathrm{E}_{\omega}\left(\pi_{\omega}\right) \cdot A \cdot\left(I_{\mathrm{L}, j}-S_{\mathrm{L}, j}\right)+\mathrm{E}_{\omega}\left(\pi_{\omega}\right) \cdot A \cdot T_{\mathrm{L}, j}+p_{\mathrm{L}}\left(S_{\mathrm{L}, j}-T_{\mathrm{L}, j}\right)\right]+ \\
& -D_{j}-I_{\mathrm{H}, j}-I_{\mathrm{L}, j}+w_{i n t}-r D_{j} .
\end{aligned}
$$

The term in the first squared brackets is the return earned at $t=2$ on the $I_{\mathrm{H}, j}$ riskless projects that the intermediary has financed or purchased in the market (for net amount $T_{\mathrm{H}, j}-S_{\mathrm{H}, j}$ ), plus the revenue earned at $t=0$ from the net sales of safe projects at unit price $p_{\mathrm{H}}$.

The term in the second squared brackets captures the same payoff for risky projects, with the key difference being that the expected return $\mathrm{E}_{\omega}\left(\pi_{\omega}\right) \cdot A \cdot\left(I_{\mathrm{L}, j}-S_{\mathrm{L}, j}\right)$ on an intermediary's own investments must now be kept distinct from the return it earns on securitized risky projects bought in the market, $\mathrm{E}_{\omega}\left(\pi_{\omega}\right) \cdot A \cdot T_{\mathrm{L}, j}$. From the standpoint of the risk-neutral intermediary, $\left(I_{\mathrm{L}, j}-S_{\mathrm{L}, j}\right)$ and $T_{\mathrm{L}, j}$ are equally appealing investments, as they yield the same average return. The risk profiles of these investments are very different, however. The intermediary's own investment $\left(I_{\mathrm{L}, j}-S_{\mathrm{L}, j}\right)$ is subject to both aggregate and idiosyncratic risk: in state $\omega$ it yields $A$ with probability $\pi_{\omega}$ and zero otherwise. In contrast, the securitized projects are subject only to aggregate risk, for risky projects are ex-ante identical and the intermediary buys a diversified portfolio of such projects. The securitized holdings $T_{\mathrm{L}, j}$ include part of each intermediary's investment project, yielding a sure return of $\pi_{\omega} \cdot A$ in state $\omega$.

In this model, securitization and trading allow project "pooling," as well as insurance contracts (in which case the "pooler" is the insurance company). Pooling is irrelevant for riskless projects, which yield $R$ both with pooling and in isolation. In contrast, pooling of risky projects can allow intermediaries to reduce idiosyncratic risk in their balance sheets and 
risk-averse investors to achieve better diversification in their portfolios. Our model allows us to investigate when pooling occurs and how intermediaries and investors exploit it.

The third and final piece of equation (3) is the intermediary's profit at $t=0$ net of securities trading (i.e., available funds minus investment costs), minus the payment of debt at $t=2$. To ease notation, objective (3) excludes borrowing and trading in projects at $t=1$. As we argued previously, these markets are irrelevant when $\omega$ is learned perfectly at $t=1$.

The intermediary takes prices $\left(r, p_{\mathrm{H}}, p_{\mathrm{L}}\right)$ as given and maximizes its expected profit in equation (3) subject to the following constraints. First, at $t=0$ investment and net asset purchases must be financed by the intermediary's own and borrowed funds:

$$
I_{\mathrm{H}, j}+I_{\mathrm{L}, j}+p_{\mathrm{H}}\left(T_{\mathrm{H}, j}-S_{\mathrm{H}, j}\right)+p_{\mathrm{L}}\left(T_{\mathrm{L}, j}-S_{\mathrm{L}, j}\right) \leq w_{i n t}+D_{j} .
$$

Second, debt issuance at $t=0$ must be such that the intermediary is able to repay riskless debt in the worst possible state of its balance sheet. This implies that

$$
r D_{j} \leq R \cdot\left(I_{\mathrm{H}, j}+T_{\mathrm{H}, j}-S_{\mathrm{H}, j}\right)+\pi_{r} \cdot A \cdot T_{\mathrm{L}, j}
$$

The intermediary can pledge to the creditors: i) its return $R \cdot\left(I_{\mathrm{H}, j}+T_{\mathrm{H}, j}-S_{\mathrm{H}, j}\right)$ from riskless projects, and ii) its holdings of securitized risky projects evaluated in the worst possible aggregate payoff $\pi_{r}$, namely, $\pi_{r} \cdot A \cdot T_{\mathrm{L}, j}$. The intermediary cannot pledge nonsecuritized risky projects $\left(I_{\mathrm{L}, j}-S_{\mathrm{L}, j}\right)$ as collateral for debt payments. Vulnerable to the idiosyncratic risk of yielding zero, these projects cannot support riskless debt.

The final constraints concern the feasibility of securitization,

$$
S_{\mathrm{H}, j} \leq I_{\mathrm{H}, j}, \quad S_{\mathrm{L}, j} \leq I_{\mathrm{L}, j}
$$

which simply say that intermediaries cannot securitize more than they invest. Note that in (6) intermediaries do not re-securitize portions of the acquired pool $T_{\mathrm{L}, j}$. Since the pool is already diversified, there is no benefit from doing so. 
At prices $\left(r, p_{\mathrm{H}}, p_{\mathrm{L}}\right)$ intermediaries maximize (3) subject to (4), (5), and (6). A representative investor $i$ maximizes utility in (1) subject to the constraint that consumption at different times and states is equal to $C_{0, i}=w+D_{i}-p_{\mathrm{H}} T_{\mathrm{H}, i}-p_{\mathrm{L}} T_{\mathrm{L}, i}, C_{1, \omega, i}=0$, and $C_{2, \omega, i}=-$ $r D_{i}+R T_{\mathrm{H}, i}+\pi_{\omega} \cdot A \cdot T_{\mathrm{L}, i}$, where $D_{i}$ is investors' borrowing at $t=0$, while $T_{\mathrm{H}, i}$ and $T_{\mathrm{L}, i}$ are the investor's $t=0$ purchases of riskless and risky projects, respectively.

We now describe the equilibrium, starting with the allocation prevailing at $t=0$ and then moving to see what happens as agents learn $\omega$ at $t=1$. We focus on symmetric equilibria where all agents of a given type (intermediary or investor) make the same choices. Consistent with prior notation, index $j$ captures the actions of the representative intermediary and index $i$ captures those of the representative investor. Detailed proofs are in the Internet Appendix.

\section{A. Securitization and Leverage at $t=0$}

In equilibrium, investors lend to intermediaries (not the other way around) and the return on riskless bonds must satisfy $r \geq 1$. Since investors and intermediaries have the same time preferences, lending can only occur for investment projects, which only intermediaries have. Since investors are indifferent between consuming at $t=0,1,2$, the condition $r \geq 1$ guarantees that lending to intermediaries makes investors weakly better off than autarky. The purchase of a riskless bond and of a securitized riskless project must yield the same return:

$$
R / p_{\mathrm{H}}=r
$$

If (7) is violated, investors' preferences as to whether to buy safe debt or a safe loan are the opposite of intermediaries' preferences as to what to issue, so in equilibrium (7) must hold. 
Crucially, investors' reservation price $p_{\mathrm{L}, \mathrm{inv}}$ for securitized risky assets (i.e., the highest price at which they are willing to buy them) is equal to

$$
p_{\mathrm{L}, \mathrm{inv}}=\pi_{r} \cdot A \text {. }
$$

Infinitely risk-averse investors value a pool of risky projects at its lowest possible payoff, obtained in a recession. This is of course below these projects' average return $\mathrm{E}_{\omega}\left(\pi_{\omega}\right) \cdot A$. These points imply that in any equilibrium the following property holds:

LEMMA 1: For any given investment profile $\left(I_{\mathrm{H}, j}, I_{\mathrm{L}, j}\right)$, intermediaries are indifferent between securitizing and not securitizing riskless projects. When the riskless debt constraint (5) is slack, intermediaries are also indifferent between securitizing and not securitizing risky projects. When that constraint is binding, intermediaries strictly prefer to securitize at least some risky projects. In such equilibria, we have that $S_{\mathrm{L}, j}>0$ and risky projects are bought by intermediaries, not by investors, so $S_{\mathrm{L}, j}=T_{\mathrm{L}, j}$.

In our model, issuing riskless debt against the return on a riskless project is equivalent to selling that project to investors. Thus, securitization of riskless projects is irrelevant and riskless debt perfectly substitutes for it. We therefore focus on equilibria where $S_{\mathrm{H}, j}=0$.

Securitization of risky projects is initially irrelevant, but only until the point when the debt constraint (5) becomes binding. As intermediaries need to absorb more investor wealth to finance risky projects, they start selling them off and buying risky projects from other intermediaries. By diversifying idiosyncratic risk, such securitization creates acceptable collateral, relaxing the debt constraint (5). Indeed, the point of securitization in this model is to relax the collateral constraint. While risk-averse investors are unwilling to lend anything 
against an individual risky project (as the latter's return may be zero), they are willing to lend something against a pool of risky projects since such a pool eliminates idiosyncratic risk.

As a consequence, to obtain financing intermediaries (not investors) end up holding securitized pools of risky projects. This arrangement boosts leverage because now intermediaries can issue debt against the diversified pool of projects. As evident from equation (5), by buying an extra unit of the pool, intermediaries can increase debt repayment at most up to investors' reservation price $p_{\mathrm{L}, \text { inv }}=\pi_{r} \cdot A$ for that unit.

Besides boosting leverage, this arrangement enhances risk sharing. In fact, another way to expand financing would be for investors to buy a pool of risky projects on their own. However, as Lemma 1 shows, this is not the market solution, since risk-neutral intermediaries are the efficient bearers of the pool's aggregate risk and thus are willing to pay more than investors for the pool. Intermediaries are eager to hold a pool because, at a given interest rate $r$, they keep the excess return $\left[\mathrm{E}_{\omega}\left(\pi_{\omega}\right) A-r\right]$ on the pool. When $\mathrm{E}_{\omega}\left(\pi_{\omega}\right) A>r$ intermediaries essentially invest in a carry trade: they borrow at the low safe interest rate from investors, but then take on risk to gain the upside of risky projects. With infinitely risk-averse investors and risk-neutral intermediaries, there are large gains from such trade.

In sum, securitization enables intermediaries to boost leverage by pooling risky projects to eliminate idiosyncratic risk. By pledging the senior tranche of the pool to investors, they raise leverage. Combined with liquidity guarantees from safe projects, the senior tranche of the diversified pool of projects is safe, and thus serves as acceptable collateral for riskless debt. The question then arises: when does securitization take place and what does this imply for leverage, interest rates, and investments? In particular, we would 
like to know whether greater leverage is associated with larger assets of the intermediaries, and greater aggregate risk. We have the following characterization result:

PROPOSITION 1: If $E_{\omega}\left(\pi_{\omega}\right) \cdot A>1$, there are two thresholds $w^{*}$ and $w^{* *}\left(w^{* *}>w^{*}\right)$ such that, in equilibrium, intermediaries issue $D_{j}=\min \left(w, w^{* *}\right)$ and the $t=0$ allocation fulfills:

(a) If $w \leq 1-w_{\text {int }}$, investor wealth is so low that only the safe project is financed and securitization does not occur. Formally, $I_{H, j}=w_{i n t}+w, I_{L, j}=0$, and $S_{L, j}=T_{L, j}=0$. The equilibrium interest rate is $r=R$.

(b) If $w \in\left(1-w_{i n t}, R / E_{\omega}\left(\pi_{\omega}\right) \cdot A\right]$, investor wealth is sufficiently high that some risky projects are also financed, but the return on safe investments is enough to repay all debt. As a consequence, securitization does not yet occur. Formally, $I_{H, j}=1, I_{L, j}=w_{\text {int }}+w-1$, and $S_{L, j}=T_{L, j}=0$. The equilibrium interest rate is $r=E_{\omega}\left(\pi_{\omega}\right) \cdot A$.

(c) If $w \in\left(R / E_{\omega}\left(\pi_{\omega}\right) \cdot A, w^{*}\right]$, investor wealth starts to be high enough that not only are some risky projects funded, but the safe return is insufficient to repay debt. Partial securitization emerges in the amount that allows intermediaries to just absorb all investor wealth. Formally, $I_{H, j}=1, \quad I_{L, j}=w_{\text {int }}+w-1$, and $S_{L, j}=T_{L, j} \in\left(0, I_{L, j}\right)$. The equilibrium interest rate is still $r=E_{\omega}\left(\pi_{\omega}\right) \cdot A$.

(d) If $w>w^{*}$, then investor wealth is so high that many risky projects are funded and securitization is maximal. Formally, $I_{H, j}=1, I_{L, j}=w_{i n t}+\min \left(w, w^{* *}\right)-1$, and $S_{L, j}=T_{L, j}=$ $I_{L, j}$. To allow intermediaries to absorb all of investor wealth, the interest rate must fall below the (average) return $E_{\omega}\left(\pi_{\omega}\right) \cdot A$ and is a decreasing function $r(w)$ of investors' wealth. 
The details of the equilibrium, including the prices $p_{\mathrm{H}}$ and $p_{\mathrm{L}}$, are described in the proof (which also studies the case in which $\mathrm{E}_{\omega}\left(\pi_{\omega}\right) \cdot A \leq 1$ ). In Figure 2, the thick dotted line depicts the average return on investment and the bold line shows the equilibrium interest rate.

[Figure 2 here]

The interest rate, securitization, and leverage are driven by the interaction between the supply of funds, as captured by investors' wealth $w$, and the demand for funds, as captured by the return on investment and by intermediaries' ability to issue riskless debt in equation (5).

When intermediaries are able to pay interest on the debt equal to the marginal return on investment, the equilibrium interest rate is given by that return. Indeed, if $r$ fell below the marginal return on investment, intermediaries would wish to issue more debt than investors' wealth, which cannot happen in equilibrium. This is what happens in case (a), where investors' wealth is so low that only riskless projects are financed, $I_{\mathrm{H}_{*} j}=w+w_{\text {int }}$, in which case it is obvious that $r=R$. But this is also true in case (b), where investors' wealth allows some risky projects to be undertaken (i.e., $I_{\mathrm{H}, j}=1, I_{\mathrm{L}, j}=w+w_{\text {int }}-1$ ). Since investors' wealth is so low that $R \geq \mathrm{E}_{\omega}\left(\pi_{\omega}\right) \cdot A \cdot w$, intermediaries can pay the full marginal return to investors out of safe cash flows. Thus, in cases (a) and (b) investors' wealth is sufficiently low that riskless debt can be issued without securitization.

Matters are different when $w>R / \mathrm{E}_{\omega}\left(\pi_{\omega}\right) \cdot A$. Now investors' wealth is so large that the return from the limited supply of safe projects alone is insufficient to pay off debt at the marginal rate of return on investment. As (5) illustrates, to expand borrowing intermediaries must now engage in at least some securitization. In case (c), investors' wealth is not too 
large, and intermediaries can absorb this wealth by securitizing only partially. Here the interest rate can rise to the marginal product of investment to ensure that intermediaries have no appetite for further expanding securitization and borrowing beyond $w$. As a result, given that now $r=\mathrm{E}_{\omega}\left(\pi_{\omega}\right) \cdot A$ and $D_{j}=w$, equation (5) implicitly pins down securitization through the constraint

$$
\mathrm{E}_{\omega}\left(\pi_{\omega}\right) \cdot A \cdot w=R+\pi_{r} \cdot A \cdot S_{\mathrm{L}, j}
$$

where we have replaced the equilibrium condition $S_{\mathrm{L}, j}=T_{\mathrm{L}, j}$. Equation (9) holds until all projects are securitized, that is, until $S_{\mathrm{L}, j} \leq I_{\mathrm{L}, j}=w_{i n t}+w-1$. This is the case provided

$$
w \leq w^{*} \equiv \frac{R / A+\pi_{r}\left(w_{\mathrm{int}}-1\right)}{\mathrm{E}_{\omega}\left(\pi_{\omega}\right)-\pi_{r}}
$$

which highlights the role of intermediaries' own wealth and of the safe project as buffers against project risk, supporting the intermediary's ability to borrow. High intermediary wealth $w_{\text {int }}$ reduces the outside financing needs of risky projects, while the safe return $R$ creates a cushion for repaying riskless debt and financing risky projects when $r<R$.

As investors' wealth grows beyond $w^{*}$, we are in case (d). Now financing constraints become very tight and intermediaries fully securitize the risky projects financed, setting $S_{\mathrm{L}, j}=$ $I_{\mathrm{L}, j}$. In this case, the interest rate must fall below the marginal product of investment for the riskless debt constraint to be satisfied, that is, $r<\mathrm{E}_{\omega}\left(\pi_{\omega}\right) \cdot A$. This is the range in which securitization effectively allows intermediaries to obtain - on each specific unit of the pool acquired - an excess return $\left[\mathrm{E}_{\omega}\left(\pi_{\omega}\right) \cdot A-r\right]$ from the carry trade of financing risky projects with safe debt. At the equilibrium quantities of investment and securitization, $I_{\mathrm{L}, j}=S_{\mathrm{L}, j}=w_{\text {int }}$ $+w-1$, equation (5) determines the equilibrium interest rate as 


$$
r(w)=\frac{R+\pi_{r} A\left(w_{\text {int }}+w-1\right)}{w},
$$

which falls in investors' wealth $w$. As $w$ increases, there is a spiral of increasing leverage, investment, and securitization, and decreasing interest rates. This process continues as $w$ continues to rise up to the level $w^{* *}$, at which $r\left(w^{* *}\right)=$ one. At this point $r$ is at its lower bound of one. Further increases in investors' wealth beyond $w^{* *}$ cannot be absorbed by intermediaries. The spiral of leverage, investment, and securitization, and of falling interest rates has now stopped.

In sum, in our model securitization appears only when marginal risky projects are financed. It is not needed when only safe projects are financed. As investor wealth becomes so large that many risky projects must be financed, securitization combined with the pledging of AAA-rated securities and liquidity guarantees is used to accommodate growing leverage.

\section{B. The Outcome at $t=1,2$ after $\omega$ is Learned}

Given the investment and securitization patterns $\left(I_{\mathrm{H}, j}, I_{\mathrm{L}, j}, S_{\mathrm{L}, j}\right)$ at $t=0$, consider what happens after $\omega$ is learned. We focus on the most interesting case where the debt constraint (5) is binding and securitization is positive. Since investors have lent under a riskless debt contract, at $t=2$ they (in aggregate) receive - for any given $\omega-$ the promised amount

$$
r D_{j}=R \cdot I_{\mathrm{H}, j}+\pi_{r} \cdot A \cdot S_{\mathrm{L}, j}
$$

Intermediaries, on the other hand, efficiently bear the aggregate risk associated with $\omega$, but they also bear the idiosyncratic risk created by their own risky project to the extent that they only partially securitized it. For any $\omega$, at $t=1$ there are two classes of intermediaries. 
The first class consists of "successful" intermediaries, whose risky project pays out. In state $\omega$ there are by definition $\pi_{\omega}$ such intermediaries, and their $t=2$ revenues are equal to

$$
R I_{\mathrm{H}, j}+\pi_{\omega} \cdot A \cdot S_{\mathrm{L}, j}+A \cdot\left(I_{\mathrm{L}, j}-S_{\mathrm{L}, j}\right)
$$

By subtracting (12) from (13), we find that, for these successful intermediaries, profits at $t=$ 2 are equal to $\left(\pi_{\omega}-\pi_{r}\right) \cdot A \cdot S_{\mathrm{L}, j}+A \cdot\left(I_{\mathrm{L}, j}-S_{\mathrm{L}, j}\right)$. These profits accrue from the securitized pool if $\pi_{\omega}>\pi_{r}$ and from the nonsecuritized investments that pay out.

The second class consists of "unsuccessful" (and not fully diversified) intermediaries whose risky project has not paid out. The revenues of these $1-\pi_{\omega}$ intermediaries are equal to

$$
R I_{\mathrm{H}, j}+\pi_{\omega} \cdot A \cdot S_{\mathrm{L}, j}+0 \cdot\left(I_{\mathrm{L}, j}-S_{\mathrm{L}, j}\right)
$$

By subtracting (12) from (14), we find that, for these "unsuccessful" intermediaries, profits at $t=2$ are equal to $\left(\pi_{\omega}-\pi_{r}\right) \cdot A \cdot S_{\mathrm{L}, j}$. All these profits accrue from holding the upside of the securitized pool of assets. When securitization is full $\left(S_{\mathrm{L}, j}=I_{\mathrm{L}, j}\right)$, there is no distinction between successful and unsuccessful intermediaries. All intermediaries earn the same profits $\left(\pi_{\omega}-\pi_{r}\right) \cdot A \cdot I_{\mathrm{L}, j}$ in (13) and (14). This observation will turn out to be critical to understanding the link between securitization and fragility.

From this analysis, we can draw the following lessons. When all market participants hold rational expectations, securitization facilitates a better allocation of risks, boosts leverage and thus productive investment, and improves welfare. It allows the extremely riskaverse investors to shed all of their risks, while risk-neutral market participants (intermediaries) are happy to bear all the residual risk to earn the extra return. As long as all investors understand the risks, the system is stable and there is no link between securitization and fragility. Full securitization eliminates idiosyncratic risk and creates stability. Even when securitization is only partial, investors anticipate that some idiosyncratic risk will turn out 
badly, which reduces the ability of any individual intermediary to borrow, so that even expost unsuccessful intermediaries are able to repay their debt.

This analysis of shadow banking explains several empirical phenomena. It accounts for the role of extremely risk-averse investors in driving the demand for securitization (Caballero, Farhi, and Gourinchas (2008), Krishnamurthy and Vissing-Jorgensen (2008)). It explains how leverage and assets of intermediaries grow together (Adrian and Shin (2010)). It further explains how, in equilibrium, intermediaries pursuing a carry trade take marginal risky projects when interest rates are low (Greenwood and Hanson (2011), Maddaloni and Peydro (2011)), and how, through securitization, intermediaries become endogenously interconnected (Allen, Babus, and Carletti (2012)). Finally, it explains how diversification of

idiosyncratic risk through securitization concentrates systematic risks on the books of financial intermediaries (Acharya, Schnabl, and Suarez (2012)). Under rational expectations, however, all these developments are benign.

At the same time, the shadow banking system is vulnerable to unanticipated shocks. Its enormous size when outside investor wealth is high, the extreme distaste of those investors for bearing any risk that consequently piles up these risks with intermediaries, and the role of securitization in increasing leverage all render shadow banking vulnerable to shocks. When we add such shocks to the model in the form of neglected low probability tail risks, the system becomes fragile. Shadow banking provides illusory rather than true insurance to investors, and as such it massively misallocates risk.

\section{Local Thinking}


We model local thinking by assuming, following Gennaioli and Shleifer (2010) and GSV (2012), that at $t=0$ both investors and intermediaries only think about the two most likely states. Recall that recession is the least likely state (i.e., $\varphi_{g}>\varphi_{d}>\varphi_{r}$ ). This prior distribution reflects a period of economic prosperity. At $t=0$ expectations are thus formed based on the restricted state space $\Omega^{\mathrm{LT}} \equiv\{g, d\}$, covering only the possibilities of growth and downturn. Superscript LT denotes the information set and beliefs of a local thinker.

There is a superficial tension between our assumptions of infinite risk aversion of investors and their neglect of tail downside risk. Shouldn't infinite risk aversion imply extreme alertness to precisely such risks? The answer, in our view, is no. First, one assumption concerns preferences and the other concerns beliefs, which are logically separate. Experimental evidence suggests that individuals overweigh small probability events when they are salient, but ignore them when they do not come to mind (Kahneman and Tversky (1979), Bordalo, Gennaioli, and Shleifer (2012)). Evidence on the forecasts of housing prices (Gerardi et al. (2008)) and on models used by rating agencies (Jarrow et al. (2007), Coval, Jurek, and Stafford (2009a)) shows that the events that ultimately occurred were too extreme to even be contemplated in advance. Second, investors' misperception may have been reinforced by AAA ratings, issued by rating agencies using quantitative models and historical data. The ratings intended to reassure infinitely risk-averse investors that these securities met their tastes.

Unlike in GSV (2012), market participants are fully aware that intermediaries are subject to the idiosyncratic risk of obtaining a zero payoff. The subtler failure of rationality here is that market participants neglect the aggregate risk that only as few as $\pi_{r}$ intermediaries may be successful. Given the technology of equation (2), this neglect creates 
two problems. First, it induces overoptimism about the average return of an individual intermediary, $\mathrm{E}_{\omega}^{\mathrm{LT}}\left(\pi_{\omega}\right) \cdot A>\mathrm{E}_{\omega}\left(\pi_{\omega}\right) \cdot A$. Second, it induces market participants to neglect the fact that an intermediary may be unsuccessful precisely in a state - a recession with aggregate payoff $\pi_{r} \cdot A$ - in which many other intermediaries are also unsuccessful. This second effect plays some role in Section III.B, but will be especially important in Section IV.

\section{A. Securitization and Leverage at $t=0$ under Local Thinking}

Since expectations are the only object that changes relative to the case with full rationality, the equilibrium at $t=0$ is isomorphic to the rational expectations equilibrium of Proposition 1, except that: i) the true expected return $\mathrm{E}_{\omega}\left(\pi_{\omega}\right) \cdot A$ is replaced by the local thinker's expected return $\mathrm{E}_{\omega}^{\mathrm{LT}}\left(\pi_{\omega}\right) \cdot A=\mathrm{E}\left(\pi_{\omega} \mid \omega=g, d\right) \cdot A$ and ii) the worst-case contemplated scenario is now a downturn rather than a recession. Thus, when valuing different securities the local thinker fails to account for their exposure to the recession. This neglect of risk implies that the thresholds $w^{*}$ and $w^{* * *}$ of Proposition 1 are replaced by $w^{* \text { LT }}$ and $w^{* *, \mathrm{LT}}$ and one can check that $w^{* * \text { LT }}>w^{* *}$ while $w^{* \text { LT }}$ may be above or below $w^{*}$. The equilibrium is characterized by Proposition 2.

PROPOSITION 2: In equilibrium under local thinking, for any given level of investors' wealth $w$ :

(a) The interest rate is weakly higher than under rational expectations, $r^{L T} \geq r$.

(b) Debt (and thus investment) is weakly higher than under rational expectations, $D^{L T} \geq D$.

(c) Securitization arises for lower levels of wealth $w$ than under rational expectations, and for $w$ sufficiently large is higher than under rational expectations, $S_{\mathrm{L}}^{\mathrm{LT}} \geq S_{L}$. 
To see the above results, note that the debt constraint under local thinking becomes

$$
r D_{j}^{\mathrm{LT}} \leq R \cdot I_{\mathrm{H}, j}^{\mathrm{LT}}+\pi_{d} \cdot A \cdot S_{\mathrm{L}, j}^{\mathrm{LT}}
$$

Under rational expectations, the corresponding expression was $r D_{j} \leq R \cdot I_{\mathrm{H}, \mathrm{j}}+\pi_{r} \cdot A \cdot S_{\mathrm{L}, \mathrm{j}}$. The shadow value of securitization is higher under local thinking: an extra securitized project expands leverage by $\pi_{d} \cdot A$ under local thinking but only by $\pi_{r} \cdot A$ under rational expectations. The insurance mechanism provided by securitization is believed to be very effective by local thinkers because in the worst-case scenario they consider a sizeable share $\left(\pi_{d}\right)$ of the pooled projects succeed. This is not so under rational expectations, where only $\pi_{r}$ of the projects are expected to succeed for sure.

This property implies that local thinking tends to boost the amount of debt repayment that can be sustained by securitization, but it does not say whether this boost will trigger an upward adjustment in the interest rate $r$ or in the amount of leverage $D^{\mathrm{LT}}$ and investment $I^{\mathrm{LT}}$. Figure 3 graphically addresses this question for the case in which $w^{*, \mathrm{LT}}<w^{*}$.

[Figure 3 here]

The bold and dashed lines plot the equilibrium interest rate under local thinking and rational expectations, respectively. The lines differ in the range in which risky projects are undertaken, as local thinking intermediaries believe the return on these projects to be higher than under rational expectations. This boosts the interest rate to $r=\mathrm{E}_{\omega}^{\mathrm{LT}}\left(\pi_{\omega}\right) \cdot A$ and tightens debt constraints, forcing intermediaries to securitize starting at lower wealth levels and more extensively (indeed, $R / \mathrm{E}_{\omega}^{\mathrm{LT}}\left(\pi_{\omega}\right) \cdot A<R / \mathrm{E}_{\omega}\left(\pi_{\omega}\right) \cdot A$ ). As long as $w \leq w^{* *}$, intermediaries absorb all 
of investors' wealth under both rational expectations and local thinking, so investment is the same in two cases (i.e., $I_{\mathrm{L}}=I_{\mathrm{L}}^{\mathrm{LT}}=w+w_{\text {int }}-1$ ). In this range, the greater pace of securitization prevailing under local thinking just reflects a rat race among intermediaries that results in a higher interest rate, not in higher investment. As we will see, this implies that over some range, securitization creates fragility without an ex-ante benefit of greater investment.

In the range $w \geq w^{* *}$, local thinking fosters not only securitization, but also leverage and investment beyond the level prevailing under rational expectations. As investors' wealth becomes very high, the interest rate must fall in order for intermediaries to absorb that wealth, but relatively less so under local thinking. Until wealth reaches $w^{* *, \mathrm{LT}}$, the shadow value of securitization under local thinking allows intermediaries to absorb more wealth from investors and to pay them a higher interest rate than under rational expectations. For $w>$ $w^{* *, \mathrm{LT}}$, the interest rate under local thinking reaches its minimum of one and no more investor wealth can be absorbed. Now the only difference with rational expectations is reflected in the amount of leverage, which is higher under local thinking.

In sum, at $t=0$ local thinking boosts the use of securitization relative to rational expectations, resulting in a higher interest rate only (for $w \leq w^{* *}$ ), in higher borrowing and a higher interest rate (for $w^{* *}<w<w^{* *, \mathrm{LT}}$ ), or in higher borrowing only (for $w \geq w^{* *, \mathrm{LT}}$ ). Similar effects are at play when $w^{* \text { LT }}>w^{*}$. We now consider the implications of this feature for the reaction of markets to news at $t=1$.

\section{B. Securitization and Fragility at $t=1$ under Local Thinking}


Consider the investment and securitization profile $\left(I_{\mathrm{H}, j}^{\mathrm{LT}}, I_{\mathrm{L}, j}^{\mathrm{LT}}, S_{\mathrm{L}, j}^{\mathrm{LT}}\right)$. If the state is growth or downturn, idiosyncratic shocks affect the profit of specific intermediaries, but riskless projects and securitized assets provide intermediaries with enough resources to repay their debt a $t=2$. When the realized $\omega$ is in the support of the states considered by the local thinker, the outcome is qualitatively similar to that arising under rational expectations.

Matters change drastically in a recession. Now intermediaries realize that at $t=2$ they may not have enough resources to repay their debt, thereby precipitating a default. To see how this possibility arises, consider the debt constraint of equation (15). Since by Lemma 1 securitization is used when this constraint is binding, in any equilibrium with positive securitization the intermediary at $t=0$ commits to repay at $t=2$ the amount

$$
r^{\mathrm{LT}} D^{\mathrm{LT}}=R \cdot I_{\mathrm{H}, j}^{\mathrm{LT}}+\pi_{d} \cdot A \cdot S_{\mathrm{L}, j}^{\mathrm{LT}}
$$

Consider now the ability of different intermediaries to repay this debt. The measure $\left(1-\pi_{r}\right)$ of unsuccessful intermediaries learns that their $t=2$ operating profits are equal to

$$
R \cdot I_{\mathrm{H}, j}^{\mathrm{LT}}+\pi_{r} \cdot A \cdot S_{\mathrm{L}, j}^{\mathrm{LT}}+0 \cdot\left(I_{\mathrm{L}, j}^{\mathrm{LT}}-S_{\mathrm{L}, j}^{\mathrm{LT}}\right) .
$$

By subtracting equation (16) from (17), we see that unsuccessful intermediaries default at $t=$ 2 because their operating profits are below the face value of debt by the amount $\left(\pi_{d}-\pi_{r}\right) \cdot A$. $S_{\mathrm{L}, j}^{\mathrm{LT}}>0$. The neglect of the risk of a recession plays a key role here: even though intermediaries try to keep their debt safe by insuring against idiosyncratic risk, the fact that the securitized pool performs worse than expected by $\left(\pi_{d}-\pi_{r}\right)$ reveals that debt is risky and triggers a default. This problem arises because the local thinker neglects the possibility that an adverse idiosyncratic shock, against which the intermediary is insured, occurs precisely in a recession state when many other intermediaries are experiencing the same shock. 
The measure $\pi_{r}$ of successful intermediaries learns that their $t=2$ profits are equal to

$$
R \cdot I_{\mathrm{H}, j}^{\mathrm{LT}}+\pi_{r} \cdot A \cdot S_{\mathrm{L}, j}^{\mathrm{LT}}+A \cdot\left(I_{\mathrm{L}, j}^{\mathrm{LT}}-S_{\mathrm{L}, j}^{\mathrm{LT}}\right) .
$$

By subtracting equation (16) from (18), we see that successful intermediaries may or may not be able to repay their debt. In particular, equation (18) is higher than (16) and thus successful intermediaries are solvent if and only if

$$
\frac{I_{\mathrm{L}, j}^{\mathrm{LT}}}{S_{\mathrm{L}, j}^{\mathrm{LT}}}>1+\left(\pi_{d}-\pi_{r}\right) .
$$

This is a key equation. It says that for successful intermediaries not to default, the fraction of risky investment that is nonsecuritized must be sufficiently high relative to the cash flow shortfall resulting from their neglect of aggregate downside risk. If securitization is close enough to zero, condition (19) is satisfied and successful intermediaries repay their debt. In this case, after the unexpected recession occurs, a share $1-\pi_{r}$ of intermediaries defaults but a (potentially high) share $\pi_{r}$ of intermediaries does not. If instead securitization is close to full $\left(S_{\mathrm{L}, j}^{\mathrm{LT}} \approx I_{\mathrm{L}, j}^{\mathrm{LT}}\right)$, even successful intermediaries default. In this case, all intermediaries default! When securitization is full, with probability $\varphi_{g}$ intermediaries get a true bonanza payoff, but when their luck turns sour, with probability $\varphi_{r}$ they get a fouled carry trade and financial distress. Interestingly, equation (19) reveals that financial fragility results from the combination of the neglect of risks and high investor wealth through the volume of securitization $S_{\mathrm{L}, j}^{\mathrm{LT}}$. Even if the neglect of risk is small, formally, $\pi_{d} \cong \pi_{r}$, the financial system can collapse when investor wealth is so large that securitization is massive.

Somewhat paradoxically, the more intermediaries insure against idiosyncratic risk, the more they become exposed to unexpected and adverse aggregate shocks. The problem is that 
securitization does not only dampen the fluctuations in intermediaries' balance sheets, but also allows them to take on more leverage. It is precisely this boost in leverage financing carry trades that renders intermediaries fragile. The combination of insurance and leverage is problematic because it creates a large correlation among intermediaries' response to neglected risks, de facto transforming riskless debt claims into catastrophe bonds, as noted by Coval, Jurek, and Stafford (2009b). This last point can be readily seen in the previous formalism: when condition (19) is not met, conditional on the realization of the unexpected state, a nonsecuritized (risky) debt claim defaults with probability $1-\pi_{r}$, whereas an allegedly safe fully securitized debt claim defaults with probability one!

By endogenizing leverage and securitization, our model allows us to determine when condition (19) is met and when it is not.

COROLLARY 1: If $E_{\omega}\left(\pi_{\omega}\right) \cdot A>1$, then there is a threshold $\underline{w} \in\left(R / \mathrm{E}_{\omega}^{\mathrm{LT}}\left(\pi_{\omega}\right) \cdot A, w^{*}{ }^{* L T}\right)$ such that when a recession occurs, for $w \leq R / \mathrm{E}_{\omega}^{\mathrm{LT}}\left(\pi_{\omega}\right) \cdot A$ no intermediary defaults, for $w \in\left(R / \mathrm{E}_{\omega}^{\mathrm{LT}}\right.$ $\left.\left(\pi_{\omega}\right) \cdot A, \underline{w}\right)$ only $1-\pi_{r}$ intermediaries default, and for $w>\underline{w}$ all intermediaries default.

This result highlights the role of investors' wealth, via the interest rate, in shaping financial fragility. When investors' wealth is low, borrowing is limited. Intermediaries' wealth $w_{\text {int }}$ is thus sufficient to sustain riskless borrowing, providing an effective buffer against unexpected shocks. As investors' wealth rises, intermediaries' wealth becomes too small to buffer against shocks. To sustain further borrowing, intermediaries must reduce balance sheet risk via securitization. When securitization is moderate, the unsuccessful intermediaries become vulnerable to unexpected aggregate shocks but the successful ones are 
still able to repay from the income generated by their own projects. When investors' wealth becomes very high and the interest rate very low, intermediaries boost leverage by maxing out securitization. Now all intermediaries are equally unprepared to withstand the aggregate shock. Here securitization spreads unexpected aggregate shocks across all intermediaries, leading all of them to default. Systematic risk becomes systemic.

The analysis links several aspects of the financial crisis that were previously noted but not seen as related. We have already highlighted that, even under rational expectations, our model explains the role of the world savings glut in driving securitization, the cyclical comovement of bank assets and leverage, procyclical risk-taking by banks, increasing bank interdependence, and the concentration of aggregate risks on bank balance sheets in securitization. In our model, a high level of investor wealth leads to expanded securitization, growing leverage, growing assets of the intermediary sector, lower interest rates, and increased bank risk taking. Under the neglected risk assumption, the model yields additional implications. Most importantly, it shows that the system that is highly stable under rational expectations becomes extremely fragile and sensitive to tail risks because securitization entails increasing bank interdependence. It also delivers the important prediction that securities perceived to be completely safe (AAA-rated) and used by banks as collateral to raise safe outside debt suffer losses when tail risks are realized. Bank losses in a crisis come precisely from these AAA-rated securities created by tranching diversified portfolios of projects (Benmelech and Dlugosz (2009)). In Section IV, we show how an extension of the model also explains liquidity dry-ups in a crisis.

The source of fragility is the neglect of aggregate risk. Unlike in the case of rational expectations, where securitization allows an appropriate increase in leverage and investment, 
when market participants are local thinkers, securitization sustains excessive insurance and thus excessive leverage, which renders the economy very sensitive to unexpected adverse aggregate shocks. In the current model, excess securitization benefits intermediaries (who are able to exploit more profitable carry trades), but hurts investors by inducing them to overlend and by exposing them to unexpected aggregate shocks. Since risk-averse investors are inefficient bearers of this risk, excess securitization leads to a net social loss.

In an alternative, but closely related, interpretation of the model, securitization works through the creation of a standardized liquid market in whatever assets investors perceive to be safe (e.g., AAA-rated MBS). Intermediaries borrow against these "safe" assets and probably even tilt their carry trades toward these assets because they are easier to lever up. The net result is that any investor misperception of risks results in massive investment in and borrowing against this "safe" asset class, creating a situation in which all intermediaries are vulnerable to the same sectoral risk. The high correlation of defaults across intermediaries in the bad state results from loading up on exposure to this neglected risk. In our model it is diversification (and tradability, see Section IV) that creates the false perception of absolute safety and the high correlation of defaults, but the mechanism is potentially more general.

In the current model, agents learn about the neglected risk at $t=1$ but fragility and losses are realized at $t=2$, when defaults occur. In reality, in contrast, when bad news hits we often observe asset trading, price drops, and spikes in risk premia. The next section presents a modification of our basic setup where all of these features naturally emerge. Many other theories account for liquidity dry ups and spikes in risk premia, but our goal here is to show that securitization importantly contributes to their occurrence. ${ }^{5}$ 


\section{Securitization and Leverage with Slow Arrival of Information}

We modify two assumptions from the previous setup. First, we assume that a fraction of risky projects pays off its return $A$ at $t=1$ rather than at $t=2$. At $t=0$, it is not known which projects pay out early. A project not repaying early need not be unsuccessful, since some successful projects pay out late (e.g., restructured mortgages). The second departure from the previous setup is that the fraction of early-paying projects is partially informative about $\omega$, perhaps because it acts as a signal of aggregate output.

Formally, we assume that at $t=1$ either state $h$ or $l$ is realized. In state $h$, a share $q_{h}$ of intermediaries obtains $A$ on their risky projects at $t=1$, while the remaining $1-q_{h}$ intermediaries must wait until $t=2$ for their return to realize. In state $l$, a share $q_{l}<q_{h}$ of intermediaries receive $A$ on their risky projects while the remaining $1-q_{l}$ must wait until $t=$ 2 for their return to realize. As a result, $\Omega_{1} \equiv\{l, h\}$ and $\Omega_{2} \equiv\{g, d, r\}$. The share of projects paying out "early" is informative about the aggregate state: the probability that any "late" project is successful at $t=2$ is higher in state $h$ than in state $l$. We formalize this notion by assuming that the unfolding of events is captured by the following event tree (which is chosen to nest the distribution of final states previously considered):

[Figure 4 here]

In Figure 4, the nodes at $t=1$ report the share of successful intermediaries at $t=1$, while the nodes at $t=2$ report the total share of successful intermediaries (at $t=1$ and $t=2$ ). The numbers in the branches capture the probabilities of moving up or down at a given node. The aggregate state that we previously called "growth" here consists of a streak of good 
news, a "downturn" consists of a mix of good and bad news, and a "recession" is a streak of bad news. As of $t=1$, state $h$ is good news, but it remains uncertain whether the overall state is $\pi_{g}$ or $\pi_{d}$, while state $l$ is bad news but it remains uncertain whether the overall state is $\pi_{d}$ or $\pi_{r}$.

Besides their informational content, the key implication of the presence of early projects is that intermediaries may use the portion of early returns that was not pledged to creditors to buy back some debt claims in secondary markets at $t=1$. This second effect becomes critical in shaping changes in market liquidity when at $t=1$ investors realize the presence of neglected risks.

At a more technical level, the presence of "early" projects also implies that some debt repayment must occur at $t=1$ when the early projects in securitized holdings yield $q_{\omega} \cdot A \cdot S_{\mathrm{L}, j}^{\mathrm{LT}}$ (recall that there is no storage). This arrangement can be described as a long-term fully safe debt contract promising one coupon at $t=1$ and another at $t=2 .{ }^{6}$ We stress that, consistent with our prior assumption, debt continues to be fully riskless (within the states of the world that come to mind). To simplify the analysis, but with no consequence for our key results, we also assume a two-tiered seniority structure within riskless debt. The most senior riskless debt is pledged up to the safe return $R I_{H, j}^{L T}$ and gets repaid at $t=2$, while the less senior riskless debt is pledged the lowest return on the pool of securitized assets $\pi_{d} S_{L, j}^{L T}$. This second class of riskless debt gets part of its repayment at $t=1$ and part at $t=2$. The only role of this assumption is to simplify the working of secondary markets at $t=1$, effectively turning them into markets where securitized pools are re-traded. 


\section{A. Securitization, Liquidity and Financial Fragility}

To study the model, we focus on the case of local thinking. Consistent with the previous analysis, we model local thinking by assuming that at $t=0$ agents only think about the two most likely paths in the tree. Under the assumption $\varphi_{d}>\varphi_{r} /\left(\varphi_{g}+\varphi_{r}\right)$, which we impose throughout, the most likely paths are growth and downturn, so that at $t=0$ local thinkers prune the lower branch of the tree, considering only the upper one:

[Figure 5 here]

Upon observing the neglected state $q_{l}$ at $t=1$, the only possible paths lead to a downturn or a recession. Market participants realize that they are in the lower branch of the tree, and take the previously neglected risk of a recession into account.

Consider the optimal policy of intermediaries at $t=0$. Given the event tree in Figure 5 , the investment-financing policies of intermediaries are isomorphic to those described in Section III.A under local thinking and full revelation of information. First, since investors are indifferent between consuming at different dates, at $t=0$ they do not care about the timing of returns and lend the same amount they lent when they fully learned $\omega$ at $t=1$ and consumed only at $t=2$. The only technical difference is that now Figure 5 implies that the local thinker's expected return is equal to $\mathrm{E}_{\omega}\left(\pi_{\omega} \mid t=0\right) \cdot A=\left\lfloor\left(\varphi_{g}+\varphi_{r}\right) \pi_{g}+\varphi_{d} \pi_{d}\right\rfloor \cdot A$, which differs from the average return expected by the local thinker in the static setup of Section II.

Second, at any investment-securitization profile $\left(I_{\mathrm{H}, j}^{\mathrm{LT}}, I_{\mathrm{L}, j}^{\mathrm{LT}}, S_{\mathrm{L}, j}^{\mathrm{LT}}\right)$, the supply of riskless bonds by intermediaries at $t=0$ is unaffected by either of our new assumptions: the presence 
of "early" projects or partial learning. The maximum amount of riskless cash flow that intermediaries can pledge is equal to the safe return $R \cdot I_{\mathrm{H}, j}^{\mathrm{LT}}$ plus the early return from securitization $q_{h} \cdot A \cdot S_{\mathrm{L}, j}^{\mathrm{LT}}$, plus the "late" return from securitization $\left(\pi_{d}-q_{h}\right) A \cdot S_{\mathrm{L}, j}^{\mathrm{LT}}$ valued at the worst state investors are thinking about. The riskless debt constraint faced by intermediaries at $t=0$ is thus given by

$$
r D_{j} \leq R \cdot I_{\mathrm{H}, j}^{\mathrm{LT}}+\pi_{d} \cdot A \cdot S_{\mathrm{L}, j}^{\mathrm{LT}},
$$

which is identical to equation (15) prevailing under full information revelation. Once again, the form of the debt constraint (20) is due to the fact that we focus on riskless debt. Section IV.B, however, shows that under the assumption of slow information arrival, intermediaries may boost debt capacity by issuing risky debt.

Although early projects and slow information arrival do not change the results of Proposition 2 concerning the $t=0$ equilibrium prevailing under local thinking, this is not so outside of normal times, in the unexpected aggregate state $q_{l}$ at $t=1$. Now matters become very different. If at $t=1$ market participants observe an unexpectedly low share $q_{l}$ of "early" projects, they realize that they are in the lower branch of the tree in Figure 4, which they had previously neglected.

As in the local thinking analysis of Section III.B, investors now suddenly realize that what can be pledged in the worst state of nature by each intermediary from its own securitized holdings $S_{\mathrm{L}, j}^{\mathrm{LT}}$ drops by the amount $\left(\pi_{d}-\pi_{r}\right) A \cdot S_{\mathrm{L}, j}^{\mathrm{LT}} \cdot{ }^{7}$ Most important, since at $t=1$ there is residual uncertainty as to whether the final state is recession or downturn, there is residual risk in the claim held by investors. Since investors are not efficient bearers of this risk, there is a rationale for them to sell their (now risky) debt claim to risk-neutral 
intermediaries. This is particularly problematic for "late" intermediaries whose risky project has not paid at $t=1$, as the debt they issued against securitized pools now faces a severe risk of default (the fact that only securitized debt claims are subject to default risk is due to our simplifying assumption of a two-tiered debt seniority structure).

To see this, consider the securitized assets of a generic late intermediary. Upon observing $q_{l}$, the investors that had been pledged up to $\pi_{d} \cdot A \cdot S_{\mathrm{L}, j}^{\mathrm{LT}}$ by the intermediary from these assets effectively become owners of the cash flow generated by these assets and value it at the worst-case value $\pi_{r} \cdot A \cdot S_{\mathrm{L}, j}^{\mathrm{LT}} \cdot 8$ On the demand side, an early intermediary having some spare liquidity at $t=1$ has a higher reservation price $\mathrm{E}\left(\pi_{\omega} \mid \omega=l\right) \cdot A \cdot S_{\mathrm{L}, j}^{\mathrm{LT}}\left(>\pi_{r} \cdot A \cdot S_{\mathrm{L}, j}^{\mathrm{LT}}\right)$ for the cash flow generated by the securitized assets of a late intermediary. To reiterate, there are gains for risk-averse investors to sell their risky debt claims on late intermediaries to the riskneutral early intermediaries having some spare liquidity at $t=1$, and for these intermediaries to purchase this debt. Notwithstanding these gains, the key question is what volume of trade can be sustained at $t=1$ by the wealth of the $q_{l}$ early intermediaries confronted with the supply of the securitized (now risky) debt of the remaining $\left(1-q_{l}\right)$ late intermediaries.

To determine the equilibrium, denote by $V_{1}$ the total market value of this now risky debt at $t=1$. Even if $V_{1}$ is below their valuation, early intermediaries are only able to buy debt to the extent that they have enough resources available. At $t=1$, the total resources available to early intermediaries to buy debt claims in secondary markets are equal to

$$
q_{l} \cdot\left[A \cdot\left(I_{\mathrm{L}, j}^{\mathrm{LT}}-S_{\mathrm{L}, j}^{\mathrm{LT}}\right)-\left(\pi_{d}-\pi_{r}\right) A \cdot S_{\mathrm{L}, j}^{\mathrm{LT}}\right],
$$

which consists of the payoff from "early" projects that were not securitized (and thus not pledged to creditors) minus the unexpected drop in the lowest value of the securitized assets 
pledged to creditors, which must be repaid using nonpledged resources. Since riskless debt is senior to equity, the intermediary must pledge part of the return from early projects to its creditors, because the pool of risky projects cannot alone ensure that debt is repaid in full. Using (21) we can prove the following result:

PROPOSITION 3: If the share of early projects is $q_{\text {l, }}$ the equilibrium at $t=1$ is as follows:

(a) If $\frac{I_{\mathrm{L}}^{\mathrm{LT}}}{S_{\mathrm{L}}^{\mathrm{LT}}}>1+\left(\pi_{d}-\pi_{r}\right)+\frac{\left(1-q_{l}\right)}{q_{l}} \mathrm{E}_{\omega}^{\mathrm{LT}}\left(\pi_{\omega} \mid \omega=l\right)$, then early intermediaries have a lot of spare wealth at $t=1$ and thus absorb all of the now risky debt, bidding up its market value to their reservation value $V_{l}=\left(1-q_{l}\right) \cdot E\left(\pi_{\omega} \mid \omega=l\right) \cdot A \cdot S_{\mathrm{L}, j}^{\mathrm{LT}}$.

(b) If $\frac{I_{\mathrm{L}}^{\mathrm{LT}}}{S_{\mathrm{L}}^{\mathrm{LT}}} \in\left[1+\left(\pi_{d}-\pi_{r}\right)+\frac{\left(1-q_{l}\right)}{q_{l}} \pi_{d}, 1+\left(\pi_{d}-\pi_{r}\right)+\frac{\left(1-q_{l}\right)}{q_{l}} \mathrm{E}_{\omega}^{\mathrm{LT}}\left(\pi_{\omega} \mid \omega=l\right)\right]$, then early intermediaries have a medium amount of spare wealth at $t=1$. They still absorb all of the now risky debt but now the market value of debt is $V_{l}=q_{l} \cdot\left[A \cdot\left(I_{\mathrm{L}, j}^{\mathrm{LT}}-S_{\mathrm{L}, j}^{\mathrm{LT}}\right)-\left(\pi_{d}-\pi_{r}\right) A \cdot S_{\mathrm{L}, j}^{\mathrm{LT}}\right]$, which is lower than intermediaries' reservation price.

c) If $\frac{I_{\mathrm{L}}^{\mathrm{LT}}}{S_{\mathrm{L}}^{\mathrm{LT}}}<1+\left(\pi_{d}-\pi_{r}\right)+\frac{\left(1-q_{l}\right)}{q_{l}} \pi_{d}$, then early intermediaries have little spare wealth at $t$ = 1. Now they cannot absorb all of the now risky debt, whose equilibrium price stays at investors' reservation value $V_{l}=\left(1-q_{l}\right) \cdot \pi_{r} \cdot A \cdot S_{\mathrm{L}, j}^{\mathrm{LT}}$.

In cases $(a)-(c)$ the ratio $I_{\mathrm{L}}^{\mathrm{LT}} / S_{\mathrm{L}}^{\mathrm{LT}}$ and the difference $I_{\mathrm{L}, j}^{\mathrm{LT}}-S_{\mathrm{L}, j}^{\mathrm{LT}}$ fall with investors' wealth $w$.

Proposition 3 shows that securitization creates financial fragility not only by exposing unsuccessful intermediaries to unexpected aggregate shocks as we saw in Section III.B, but 
also by draining out market liquidity after the unexpected shock has occurred. When a large share of investment is securitized (i.e., $I_{\mathrm{L}, j}^{\mathrm{LT}}-S_{\mathrm{L}, j}^{\mathrm{LT}}$ is low), even intermediaries with "early" projects are illiquid when the unexpected shock occurs, because they had sold part of their successful projects to other intermediaries and they increased their leverage. This implies that even if the unsecuritized part of the portfolio is sufficiently large to allow "early" intermediaries to repay their own creditors, these intermediaries are unable to provide liquidity backstop to other creditors by purchasing the distressed debt claims of the "late" intermediaries. Once more, initial investor wealth is critical in creating financial fragility, for it is precisely when investors' wealth is high that securitization and leverage are extensive, causing secondary debt markets to be fragile. ${ }^{9}$

In Shleifer and Vishny (2010) and GSV (2012), market liquidity is scarce because the investment gains reaped by intermediaries induce them to commit all of their wealth at $t=0$. In our model, in contrast, the insurance mechanism provided by securitization boosts fragility not only by inducing intermediaries to commit their wealth ex-ante, but also and most distinctively by rendering the "spare wealth" conditions of different intermediaries highly correlated. In fact, the model in GSV can be viewed as a special case of this model in the range where securitization is full so that idiosyncratic risk is fully removed.

The case with partial securitization highlights the distinctive mechanism through which insurance creates fragility. In that case, it is still true that some unsuccessful intermediaries experience financial distress because, as in Shleifer-Vishny (2010) and GSV (2012), they have committed all of their wealth to investment. However, successful intermediaries with unencumbered balance sheets are able to provide liquidity support. 
These intermediaries have also committed all of their wealth ex-ante, but limited securitization leaves them with some spare capacity to rescue the unsuccessful intermediaries thanks to the bonanza of early successful projects. Markets are liquid in the sense of Shleifer and Vishny (1992, 1997), Acharya and Pedersen (2005), and Brunnermeier and Pedersen (2009). With more extensive securitization, however, the spare capacity of successful intermediaries does not suffice to provide backstop insurance to the unsuccessful ones. By creating a correlation in the performance of different intermediaries through an endogenously created network of relationships, securitization creates market illiquidity. This correlation can be viewed as a source of counterparty risk created by the interlinkages typical of insurance arrangements, generating systemic risk in the sense of Giglio (2010).

\section{B. Risky Debt and Risk Premia}

The previous analysis shows how trading and liquidity of riskless debt is shaped by securitization after the realization of neglected risks, but does not meaningfully explain changes in risk premia since risk-averse investors do not hold risky securities. In our model, securitization and its link to financial fragility also have implications for risk premia.

To begin, note that the presence of "early" projects may allow intermediaries to expand debt capacity by issuing risky debt to investors. So far we have only considered the issuance of riskless debt claims pledging the lowest support of the risky pool $\pi_{d} \cdot A \cdot S_{\mathrm{L}, j}^{\mathrm{LT}}$ (on top of the riskless return $R I_{\mathrm{H}, j}^{\mathrm{LT}}$ ). However, the intermediary could issue a (risky) debt security that pledges the entire cash flow from the pool, or equivalently it pledges the risky pool as collateral, effectively using securitization not only as pooling but also as a ring- 
fencing device. Crucially, investors are willing to lend up to $p_{1} \cdot S_{\mathrm{L}, j}^{\mathrm{LT}}$ for this security, where $p_{1}$ is the market value of risky collateralized debt at $t=1$ in the event tree of Figure 5 that agents are thinking about. If investors expect to resell the pool at $t=1$ at a price $p_{1}>\pi_{d} \cdot A$, pledging the entire pool as collateral allows intermediaries to increase the shadow value of securitization in terms of relaxing the riskless debt constraint (5), which becomes $r D_{j} \leq R$. $I_{\mathrm{H}, j}^{\mathrm{LT}}+p_{1} \cdot S_{\mathrm{L}, j}^{\mathrm{LT}}$. Debt capacity is indeed larger than in (20) precisely when $p_{1}>\pi_{d} \cdot A$. If instead investors expect a market price for risky collateral of $p_{1}=\pi_{d} A$, then posting risky collateral entails no expansion in debt capacity relative to purely riskless debt.

The possibility of market trading explains why it might indeed be the case that in equilibrium $p_{1}>\pi_{d} A$ : intermediaries holding "early" projects are willing to pay more than $\pi_{d} \cdot A$ for each unit of the pool because - being risk-neutral - they also value the pool's upside. Once again, the question is whether early intermediaries are sufficiently wealthy at $t=1$ to sustain a high market price $p_{1}>\pi_{d} \cdot A$. In the remainder of this section, we sketch the analysis of an equilibrium where $p_{1}>\pi_{d} \cdot A$. The goal of our analysis here is not to fully characterize the equilibrium set, but to identify circumstances in which the very mechanism permitting the issuance of risky debt at $t=0$ to investors - the expectation of ex-post market liquidity evaporates when neglected risks materialize, creating fragility.

Consider an equilibrium in which the price at $t=1$ is equal to intermediaries' reservation value, namely, $p_{1}=\mathrm{E}_{\omega}\left(\pi_{\omega} \mid \omega=l\right) \cdot A$. To see under what condition this equilibrium is sustainable, note that along the expected path of events at $t=1$ there is no default on debt, so that the liquid resources of intermediaries are equal to $q_{h} A \cdot\left(I_{\mathrm{L}, j}^{\mathrm{LT}}-S_{\mathrm{L}, j}^{\mathrm{LT}}\right)$. That is, intermediaries' resources are equal to the nonsecuritized (and thus nonpledged) return of the 
early projects in $h$. On the other hand, early intermediaries must absorb the market value of the totality of risky debt at their reservation price, which amounts to $\mathrm{E}_{\omega}\left(\pi_{\omega} \mid \omega=l\right) A S_{\mathrm{L}, j}^{\mathrm{LT}}$. The liquid resources of intermediaries are enough to absorb this amount when

$$
\frac{I_{\mathrm{L}}^{\mathrm{LT}}}{S_{\mathrm{L}}^{\mathrm{LT}}}>1+\frac{\mathrm{E}_{\omega}^{\mathrm{LT}}\left(\pi_{\omega} \mid \omega=h\right)}{q_{h}} .
$$

When this equilibrium is sustained, that is, (22) holds, intermediaries' debt capacity is $R \cdot I_{\mathrm{H}, j}^{\mathrm{LT}}$ $+\mathrm{E}_{\omega}\left(\pi_{\omega} \mid \omega=h\right) \cdot A \cdot S_{\mathrm{L}, j}^{\mathrm{LT}}$. For any value of $S_{\mathrm{L}, j}^{\mathrm{LT}}$, this is above their debt capacity with riskless debt in equation (20). Note that higher debt capacity does not boost aggregate borrowing because the aggregate resources available to intermediaries at $t=1$ are fixed. The main feature of this arrangement is that the same amount of borrowing can be carried out using less securitization. Due to the presence of a liquid secondary market, each unit of securitization is more valuable to investors.

Since the left-hand side $I_{\mathrm{L}, j}^{\mathrm{LT}} / S_{\mathrm{L}, j}^{\mathrm{LT}}$ of equation (22) falls with investors' wealth $w$, from subcase (c) in Proposition 1 it follows that there exists a threshold $\tilde{w}$ such that equation (22) holds for $w \in\left(R / \mathrm{E}_{\omega}\left(\pi_{\omega} \mid \omega=h\right) \cdot A, \tilde{w}\right)$. Intuitively, for a secondary market to operate at $t=1$, investors' wealth must be sufficiently large $\left[w>R / \mathrm{E}_{\omega}\left(\pi_{\omega} \mid \omega=h\right) \cdot A\right]$ that some assets are securitized. On the other hand, if investor wealth is too large, securitization is so extensive that early intermediaries are illiquid even in good times, making it impossible for them to buy all risky claims at their reservation price. Hence, we must have $w<\tilde{w}$.

In terms of the $t=0$ equilibrium, note that when $w \in\left(R / \mathrm{E}_{\omega}\left(\pi_{\omega}\right) \cdot A, \tilde{w}\right)$ securitization is partial, otherwise (22) would not hold, and thus $r=\mathrm{E}_{\omega}\left(\pi_{\omega} \mid \omega=h\right) A$, just as in subcase (c) of Proposition 1. In this equilibrium, at $t=0$ risk-averse investors buy risky debt at the 
equilibrium interest rate valuing the underlying risky collateral at $\mathrm{E}_{\omega}\left(\pi_{\omega} \mid \omega=h\right) A$, which is precisely the intermediaries' reservation price. In this precise sense, at $t=0$ the risk premium on risky debt is equal to zero. Intuitively, even if investors dislike risk, they value collateral at its risk-neutral value because they believe that tomorrow they can sell their debt in a liquid market dominated by risk-neutral investors. ${ }^{10}$

Once more, however, this arrangement is very sensitive to neglected risk. When at $t=$ 1 market participants observe a low share of "early" projects $q_{l}$, they immediately realize that, in the most optimistic scenario, they are only able to sell at the average price $\mathrm{E}_{\omega}\left(\pi_{\omega} \mid \omega=l\right) A$, which is less than what they expected to obtain at $t=0$. The unexpected bad state reduces intermediaries' valuation at $t=1$, exposing investors to resale risk. Most important, however, even if intermediaries' valuation does not change much, in the sense that $\mathrm{E}_{\omega}\left(\pi_{\omega} \mid \omega=l\right) \approx \mathrm{E}_{\omega}\left(\pi_{\omega} \mid\right.$ $\omega=h$ ), investors are also exposed to the possibility that a bad realization of a neglected risk may cause liquidity at $t=1$ to evaporate. This effect can be so strong as to drive the price of risky debt at $t=1$ down to investors' ex-post valuation, which has become equal to $\pi_{r} \cdot A$. In this case, the risk premium jumps from zero at $t=0$ to $\left[\mathrm{E}_{\omega}\left(\pi_{\omega} \mid \omega=l\right)-\pi_{r}\right] A$ at $t=1$.

We now identify the conditions leading to this case, which illustrates in the starkest manner the mechanism for fragility under risky debt. This case arises when $q_{l} A \cdot\left(I_{\mathrm{L}, j}^{\mathrm{LT}}-S_{\mathrm{L}, j}^{\mathrm{LT}}\right)$, the liquid resources of intermediaries at $t=1$, are insufficient to absorb all risky debt at investors' reservation price. This occurs provided

$$
\frac{I_{\mathrm{L}}^{\mathrm{LT}}}{S_{\mathrm{L}}^{\mathrm{LT}}}<1+\frac{\pi_{r}}{q_{l}},
$$

which holds when the nonsecuritized portion of the investment by successful intermediaries is sufficiently small. Conditions (22) and (23) are mutually consistent provided 


$$
\frac{q_{l}}{q_{h}}<\frac{\pi_{r}}{\mathrm{E}_{\omega}\left(\pi_{\omega} \mid q_{h}\right)}
$$

When (24) holds, there is a range of investor wealth levels for which intermediaries expand debt capacity by selling risky debt to investors. This debt is sold without a risk premium at $t$ $=0$, but its risk premium becomes very large when neglected risks materialize.

Here the novel aspect causing both the boom and bust in the value of debt and the fluctuation in risk premia is securitization itself. In good times, securitization reduces risk premia by creating a relatively safe and liquid form of collateral. After all, the investor thinks if the intermediary is hit by an adverse idiosyncratic shock, he can always sell its debt in the market and reduce his downside risk. This effect sustains ex-ante leverage. In bad times, however, securitization creates a strong correlation in the returns of intermediaries, which renders secondary markets illiquid after bad aggregate news. This drives risk premia up as neglected risks materialize. The problem here is that the local thinking investor neglects the possibility that the intermediary whose debt he owns goes under precisely when many other debtors go under as well. In these neglected states, the very securitization that had created the illusion of safety causes liquidity to collapse. As a consequence, the risk- averse investor is stuck with risky debt, which causes the risk premium to rise.

\section{Discussion}

In this section, we compare three theories of shadow banking and securitization, and consider their implications for the financial crisis. All three theories see securitization as meeting the demand for safe debt by pooling and tranching cash flows so as to reduce the risk of securities thus manufactured. Early research on securitization focused on how this process 
can overcome adverse selection problems (see Gorton and Pennachi (1990), De Marzo and Duffie (1999), De Marzo (2005), and Dang, Gorton, and Holmstrom (2009)). According to this "textbook" view, the essential feature of safe securities is that all investors are symmetrically informed (or ignorant) about their payoffs, and therefore can trade them without fear of being ripped off. The informational symmetry among investors creates a liquid market for safe debt. In principle, this liquid market allows banks to sell off loans and reduce the riskiness of their balance sheets. Prior to the crisis, however, banks probably retained too much risk.

The second theory, which we refer to as the "regulatory arbitrage" view, seeks to explain this puzzle of risk retention by stressing the role of distortionary financial regulation in encouraging securitization without risk transfer. Some of the key papers include Calomiris and Mason (2003), Acharya and Richardson (2009), and Acharya, Schnabl, and Suarez (2012). According to this view, banks pursued securitization through off-balance-sheet Special Investment Vehicles (SIVs) to get around capital requirements, and obtained bond ratings to go further with this activity (Ashcraft, Goldsmith-Pinkham, and Vickery (2010), Benmelech and Duglosz (2009), Stanton and Wallace (2010)). By transforming part of the assets held on their balance sheets into highly rated securities, banks were able to sustain higher leverage and still comply with risk-weighted capital requirements. The regulatory arbitrage view is often combined with the separate idea of "too big to fail," which holds that banks were willing to provide liquidity guarantees to SIVs and otherwise retain risks because they counted on a government bailout if things went badly (Acharya and Richardson (2009)). 
The third view, which we develop in this paper, also sees securitization as a mechanism of risk reallocation between risk-averse investors and risk-neutral intermediaries, but stresses the role of expectations in shaping its magnitude and efficiency.

All three views deliver some of the main facts about the shadow banking system. First, all three theories start with substantial demand for safe debt, due to regulatory, liquidity, or risk-aversion reasons. Second, they all see securitization as a financial innovation that meets this demand by pooling and tranching cash flows. Third, all three theories explain why banks retain some risk. Under the adverse selection view, banks retain risks because the securities they sell must be safe enough to avoid triggering investment in information. Under the regulatory arbitrage view, banks retain tail risks because they count on a bailout. In our model, banks are the efficient bearers of risk, and retain it efficiently (under rational expectations).

All three views also suggest how a bad shock precipitates a financial crisis. Under the adverse selection view, a piece of bad news raises the probability of default on safe debt enough to trigger investment in information by market participants. As soon as they begin such investing, market participants realize that they could be less informed than their trading counterparties and become reluctant to trade. Liquidity evaporates and markets crash. Even relatively minor news, when it precipitates a quest for information, can unravel markets.

Under the regulatory arbitrage view, a piece of bad news about cash flows, the government's commitment to bank rescues, or both can destabilize a highly leveraged bank. There could be a run on the bank, or a refusal of the lenders - the buyers of the short-term securities the bank issues - to roll over debt. When several banks experience this shock, or when banks are interdependent, the financial system can collapse. It is precisely because 
banks are able to evade capital requirements and lever up so much that they are so vulnerable to shocks.

In our theory (with neglected risk), "safe" debt is over-issued against securitized pools. When these pools are recognized to be riskier than initially believed, intermediaries experience losses and risk-averse lenders become exposed to default risk, precipitating fragility and illiquidity.

The three theories are not mutually exclusive, and all are likely to have played a role in the 2007 to 2009 crisis. The regulatory arbitrage view in particular explains some features that our model cannot, such as the dominance in securitization of the ultra-large banks, which were most likely to count on a bailout (Erel, Nadauld, and Stulz (2011)). This view is also consistent with evidence that some institutions, such as money market funds, took on more risks in 2007 even after these risks became apparent (Kacperczyk and Schnabl (2011)). ${ }^{11}$ The on-going European banking crisis seems to be caused by regulatory arbitrage, not neglect of risk.

Our paper does not address other aspects of securitization. We do not model ringfencing of collateral in securitization, which makes it available to creditors outside of bankruptcy proceedings, another feature increasing the safety of debt (Gorton and Souleles (2006), Gorton and Metrick (2012)). Nor do we model the maturity transformation and runs by short-term creditors as triggers of the crisis, elements stressed by Shin (2009), Brunnermeier (2009), and Gorton and Metrick (2010, 2012). In our view, the financial crisis had a lot to do with a massive and unanticipated shock to the assets of the financial intermediaries, and specifically assets used as collateral for short-term debt (Copeland, Martin, and Walker (2010), Krishnamurthy, Nagel, and Orlov (2011)). We see the 
withdrawal of short-term finance as largely a response to that shock and not a wholly separate cause of the crisis.

Despite these limitations, we believe that our theory is needed to explain aspects of the 2007 to 2009 crisis, largely because of the failure of markets to anticipate it. Under the pure regulatory arbitrage view, banks and other market participants were aware of the increased risks being taken prior to the crisis, but were counting on a bailout. However, if ratings were inflated through questionable financial engineering of MBS and CDOs, the spreads on such securities should still have reflected the increased risk of default, but there is evidence that they did not (Ashcraft, Goldsmith-Pinkham, and Vickery (2010), Coval, Jurek, and Stafford (2009a, 2009b), Jarrow et al. (2007)). Adelino (2009) finds that yields on different AAA-rated MBS were not predictive of subsequent performance, in contrast to the yields of lower rated securities.

One can argue of course that, ex ante, the probability that these securities would do poorly was incredibly small, so expectations were in fact rational. What we saw was a rare disaster or a perfect storm (Barro (2006), Gabaix (2012)). On this, we note two points. First, we do not claim that all tail risks are always neglected. In fact, many catastrophic events such as sovereign defaults often loom large in investors' minds, and our theory does not describe such risks. But, second, to say that some rare disasters are contemplated by markets is not to say that all of them are. We have laid out direct evidence that, in the crisis of 2007 to 2009, critical risks were underestimated. As Coval, Jurek, and Stafford (2009a, 2009b) show, as late as 2007 the prices of bonds reflect small risk premia, not large risks of default. Direct evidence on credit ratings, on models used by rating agencies, on forecasts of housing prices, and on internal communications inside financial institutions all point to a failure to 
adequately consider the possibility of a disaster. While these issues remain controversial, we believe there is a need to take neglected risks seriously as part of the narrative of the financial crisis.

Our view of the shadow banking system has several empirical implications that may help to distinguish it from the other theories discussed here. First, our view sees financial crises as manmade disasters that therefore occur more frequently than might be expected in a neoclassical framework, where market participants minimize the risks of default and bankruptcy. Our model also has the implication that a post-mortem analysis of market data shows that market participants were not fully aware of the risks being taken. Second, when key decision makers do not appreciate the risks they take, looking at management incentives cannot predict very well which institutions get into trouble. It is difficult to argue that top executives at Lehman and Bear Stearns had incentives to take big risks because they faced little downside. Third, greater securitization in our model is associated with a greater likelihood of financial fragility. Witness the speed with which the crisis unfolded in the U.S. and the U.K. versus in the rest of Europe. Finally, because investors may extrapolate past returns and become wrongly convinced of the safety of certain assets, future crises are more likely to be associated with assets that have shown little downside risk in the recent past.

\section{Conclusion}

We present a new model of shadow banking that describes securitization without any risk transfer outside the core banks. Securitization allows banks to diversify idiosyncratic risk while concentrating their exposure to systematic risk. This process enables them to expand their balance sheets by essentially funding carry trades with riskless debt. When all 
risks are recognized ex ante, this market efficiently allocates them to risk-neutral financial intermediaries, and expands opportunities for insurance and intertemporal trade. This view of securitization under rational expectations accounts for many empirical phenomena, including the role of the demand for safe debt in driving securitization, the comovement of bank assets and leverage, and the rising interdependence of banks as a byproduct of securitization. This view also suggests that the shadow banking system becomes extremely fragile when tail risks are neglected. The trouble is not the realization of neglected risks per se, but the increase in the total amount of risk-taking that securitization facilitates. Securitization magnifies exposure to unrecognized aggregate risks through contracts between intermediaries that, absent neglect, would improve welfare.

One might ask how this mechanism differs from the more basic proposition that banks often finance risky projects, such as mortgages, and occasionally face huge losses when such financing turns sour. What is new about securitization is that it enables intermediaries to access enormous pools of short-term capital seeking riskless returns even without government deposit guarantees. By identifying activities in which investors misperceive risks, perhaps because they pay too much attention to recent history, financial intermediaries can use securitization to finance a lot more risk than they could without it. The cost, of course, is that they bear the residual risk themselves. It is precisely the process of risk control through diversification and securitization that exposes all intermediaries to common risks, and generates aggregate instability in excess of what would occur if each bank speculated on its own. Moreover, because the availability of short-term finance is based on the perceived safety of publicly traded securities held by many banks, bank runs quickly turn system-wide. Insurance contracts intended to be risk-reducing end up enhancing systemic risk. 
The risks neglected by market participants tend to be subtle and constantly evolving. For this reason, it is optimistic to expect market regulators to identify these risks when investors and even intermediaries fail to do so. Still, some policy interventions might make the system more stable. The most obvious, if crude, instrument is capital requirements, which can successfully reduce the ability of intermediaries to expand their risky activities even when risks are neglected. Our model suggests that it is better to control overall bank leverage, to the extent possible, than to rely on risk-weighted capital requirements, since ratings are vulnerable to the neglect of risks. The failure of rating agencies during the crisis eloquently testifies to this effect. Alternatively, regulators might raise a red flag when they see increasing exposure of intermediaries to a particular sector, such as real estate, especially when accompanied by securitization and collateralized borrowing. Regulators might also be wary of financial innovations such as prime money market funds whose appeal consists of offering higher returns with allegedly no risk. Knowledge of which risks are neglected is not essential for recognizing the signs of such neglect in the financial system. 


\section{References}

Acharya, Viral V., and Lasse H. Pedersen, 2005, Asset pricing with liquidity risk, Journal of Financial Economics 77, 375-410.

Acharya, Viral V., and Matthew Richardson, eds., 2009, Restoring Financial Stability: How to Repair a Failed System (John Wiley \& Sons, Inc., Hoboken, NJ).

Acharya, Viral V., and Philipp Schnabl, 2010, Do global banks spread global imbalances? Asset backed commercial paper during the financial crisis of 2007-09, IMF Economic Review 58, 37-73.

Acharya, Viral V., Philipp Schnabl, Gustavo Suarez, 2012, Securitization without risk transfer, Journal of Financial Economics, forthcoming.

Adelino, Manuel, 2009, Do investors rely only on ratings? The case of mortgage-backed securities, Working paper, MIT.

Adrian, Tobias, and Hyun Song Shin, 2010, Liquidity and leverage, Journal of Financial Intermediation 19, 418-437.

Allen, Franklin, Ana Babus, and Elena Carletti, 2012, Asset commonality, debt maturity, and systemic risk, Journal of Financial Economics 104, 519-534.

Allen, Franklin, and Douglas Gale, 1994, Financial Innovation and Risk Sharing (MIT Press, Cambridge, MA).

Ashcraft, Adam, Paul Goldsmith-Pinkham, and James Vickery, 2010, MBS ratings and the mortgage credit boom, European Banking Center Discussion Paper no. 2010-24S.

Barro, Robert, 2006, Rare disasters and asset markets in the twentieth century, Quarterly Journal of Economics 121, 823-866. 
Benmelech, Efraim, and Jennifer Dlugosz, 2009, The credit ratings crisis, in Daron Acemoglu, Kenneth Rogoff, and Michael Woodford, eds.: NBER Macro Annual (National Bureau of Economic Research, Cambridge, MA).

Bernanke, Benjamin, Carol Bertaut, Laurie Ponder DeMarco, and Steven Kamin, 2011, International capital flows and the returns to safe assets in the United States, 20032007, International Finance Discussion Paper no. 1014, Federal Reserve.

Bordalo, Pedro, Nicola Gennaioli, and Andrei Shleifer, 2012, Salience theory of choice under risk, Quarterly Journal of Economics 127, 1243-1285.

Brown, Gordon, 2010, Beyond the Crash: Overcoming the First Crisis of Globalization (Free Press, New York).

Brunnermeier, Markus, 2009, Deciphering the liquidity and credit crunch 2007-08, Journal of Economic Perspectives 23, 77-100.

Brunnermeier, Markus, and Lasse Pedersen, 2009, Market liquidity and funding liquidity, Review of Financial Studies 22, 2201-2199.

Caballero, Ricardo, Emmanuel Farhi, and Pierre-Olivier Gourinchas, 2008, An equilibrium model of global imbalances and low interest rates, American Economic Review 98, 358-393.

Calomiris, Charlie, and Joseph Mason, 2003, Credit card securitization and regulatory arbitrage, Federal Reserve Board of Philadelphia Working Paper no. 03-7.

Copeland, Adam, Antoine Martin, and Michael Walker, 2010, The tri-party repo market before the 2010 reforms, Working paper, Federal Reserve Bank of New York.

Coval, Joshua, Jakub Jurek, and Eric Stafford, 2009a, The economics of structured finance, Journal of Economic Perspectives 23, 3-26. 
Coval, Joshua, Jakub Jurek, and Eric Stafford, 2009b, Economic catastrophe bonds, American Economic Review 99, 628-666.

Dang, Tri Vi, Gary Gorton, and Bengt Holmstrom, 2009, Ignorance and the optimality of debt for liquidity provision, Working paper, Yale University.

DeMarzo, Peter, 2005, The pooling and tranching of securities: A model of informed intermediation, Review of Financial Studies 18, 1-35.

DeMarzo, Peter, and Darrell Duffie, 1999, A liquidity-based model of security design, Econometrica 67, 65-99.

Diamond, Douglas, 1984, Financial intermediation and delegated monitoring, Review of Economic Studies 51, 393-414.

Erel, Isil, Taylor Nadauld, and Rene Stulz, 2011, Why did U.S. banks invest in highly-rated securitization tranches? Working paper, Ohio State University.

Fahlenbrach, Rudiger, and Rene Stulz, 2011, Bank CEO incentives and the credit crisis, Journal of Financial Economics 99, 11-26.

Gabaix, Xavier, 2012, Variable rare disasters: An exactly solved framework for ten puzzles in macro-finance, Quarterly Journal of Economics 127, 645-700.

Geanakoplos, John, 2009, The leverage cycle, in Daron Acemoglu, Kenneth Rogoff, and Michael Woodford, eds.: NBER Macro Annual (National Bureau of Economic Research, Cambridge, MA).

Gennaioli, Nicola, and Andrei Shleifer, 2010, What comes to mind, Quarterly Journal of Economics 125, 1399-1434.

Gennaioli, Nicola, Andrei Shleifer, and Robert Vishny, 2012, Neglected risks, financial innovation, and financial fragility, Journal of Financial Economics 104, 452-468. 
Gerardi, Kristopher, Andreas Lehnert, Shane Sherlund, and Paul Willen, 2008, Making sense of the subprime crisis, Brookings Papers on Economic Activity, Fall, 69-145.

Giglio, Stefano, 2010, Credit default swap spreads and systemic financial risk, Working paper, Harvard University.

Gorton, Gary, and Andrew Metrick, 2010, Regulating the shadow banking system, Brookings Papers on Economic Activity, Fall, 261-297.

Gorton, Gary, and Andrew Metrick, 2012, Securitized banking and the run on repo, Journal of Financial Economics 104, 425-451.

Gorton, Gary, and George Pennacchi, 1990, Financial intermediaries and liquidity creation, Journal of Finance 45, 49-71.

Gorton, Gary, and Nicholas Souleles, 2006, Special purpose vehicles and securitization, in Rene Stulz and Mark Carey, eds.: The Risk of Financial Institutions (University of Chicago Press for NBER).

Greenwood, Robin, and Sam Hanson, 2011, Issuer quality and corporate bond returns, Working paper, Harvard University.

Harvey, Campbell, and Akhtar Siddique, 2000, Conditional skewness in asset pricing tests, Journal of Finance 55, 1263-1295.

Jarrow, Robert, Li Li, Mark Mesler, and Donald van Deventer, 2007, CDO valuation: Fact and fiction, Kamakura Corporation Paper.

Kacperczyk, Marcin, and Philipp Schnabl, 2011, Implicit guarantees and risk-taking: Evidence from money market funds, Working paper, New York University.

Kahneman, Daniel, and Amos Tversky, 1979, Prospect theory: An analysis of decision under risk, Econometrica 47, 263-292. 
Krishnamurthy, Arvind, Stefan Nagel, and Dmitry Orlov, 2011, Sizing up repo, Working paper, Northwestern University.

Krishnamurthy, Arvind, and Annette Vissing-Jorgenson, 2008, The aggregate demand for treasury debt, Working paper, Northwestern University.

Maddaloni, Angela, and Jose-Luis Peydro, 2011, Bank risk-taking, securitization, supervision, and low interest rates: Evidence from the Euro area and U.S. lending standards, Review of Financial Studies 24, 2121-2165.

Pozsar, Zoltan, Tobias Adrian, Adam Ashcraft, and Hayley Boesky, 2010, Shadow banking, Working paper, Federal Reserve Bank of New York.

Rajan, Raghuram, 2006, Has finance made the world riskier? European Journal of Financial Management 12, 499-533.

Ross, Stephen, 1976, Options and efficiency, Quarterly Journal of Economics 90, 75-89.

Shin, Hyun Song, 2009, Reflections on Northern Rock: The bank run that heralded the global financial crisis, Journal of Economic Perspectives 23, 101-120.

Shleifer, Andrei, and Robert W. Vishny, 1992, Liquidation values and debt capacity: A market equilibrium approach, Journal of Finance 47, 1343-1366.

Shleifer, Andrei, and Robert W. Vishny, 1997, The limits of arbitrage, Journal of Finance 52, $35-56$.

Shleifer, Andrei, and Robert W. Vishny, 2010, Unstable banking, Journal of Financial Economics 97, 306-318.

Stanton, Richard, and Nancy Wallace, 2010, CMBS subordination, ratings inflation, and regulatory-capital arbitrage, NBER Working paper 16206. 


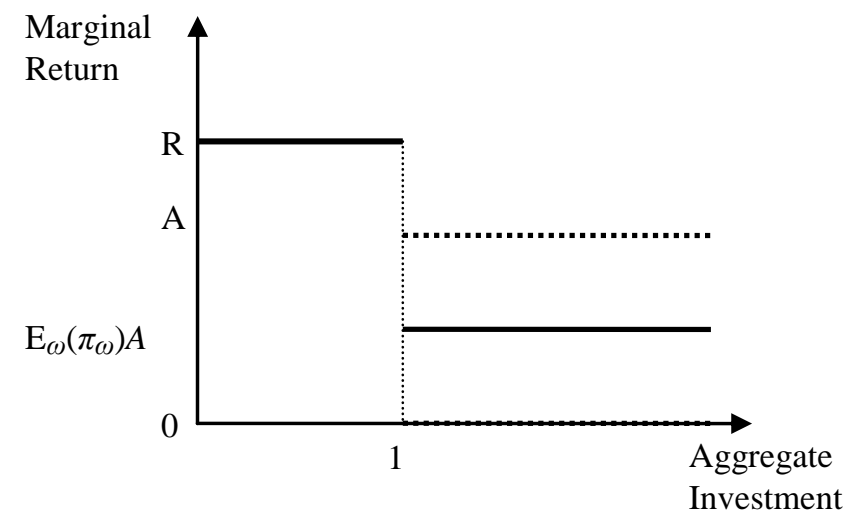

Figure 1. Marginal return on investment.

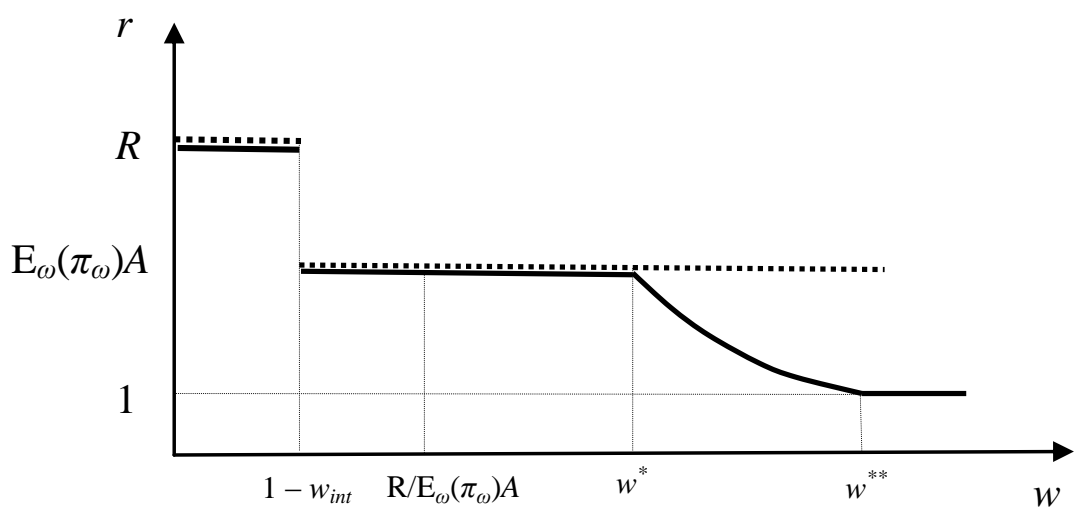

Figure 2. Interest rate, wealth, and securitization. 


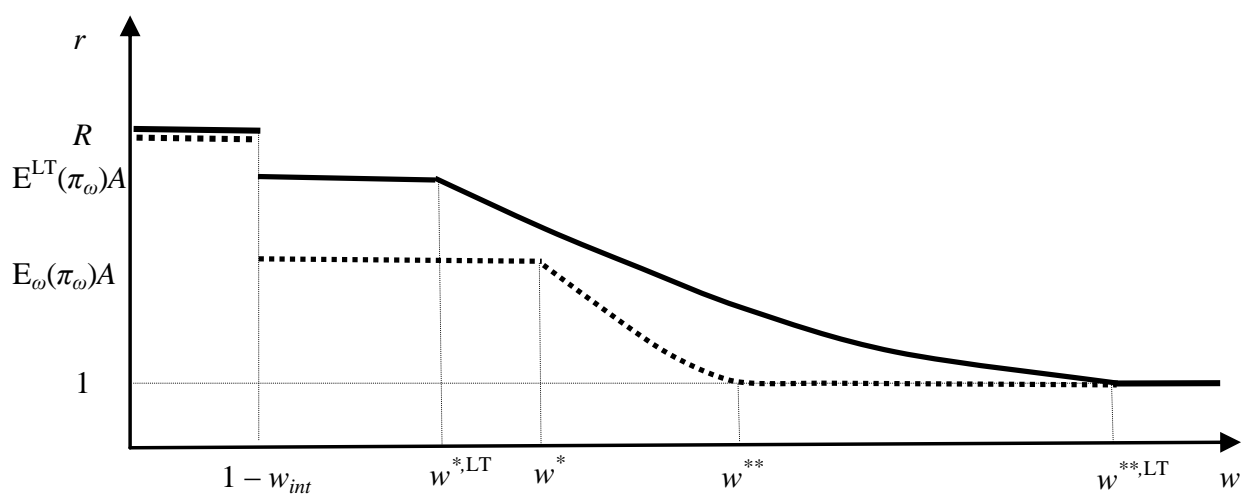

Figure 3. The interest rate under local thinking.

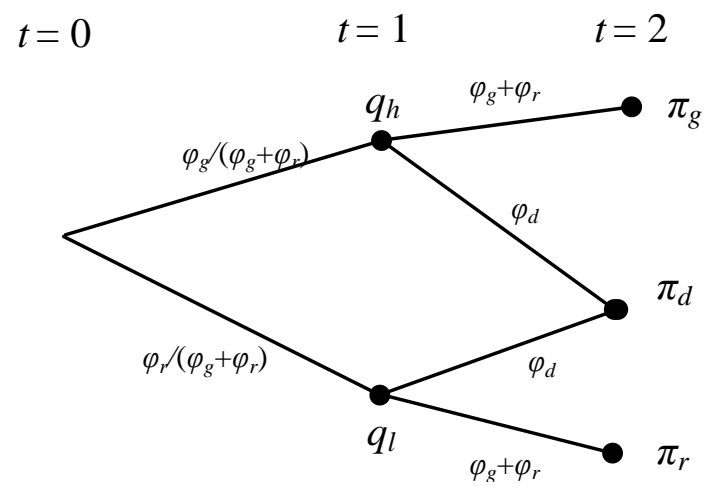

Figure 4. Information tree. 


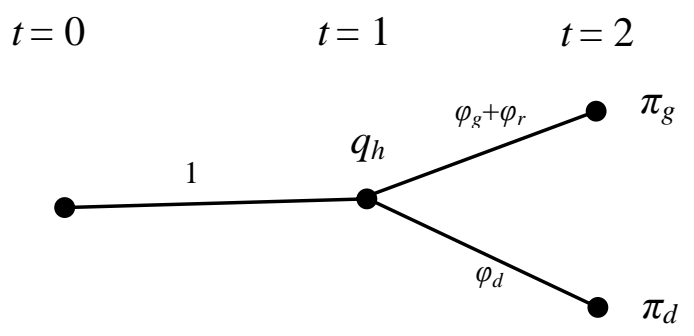

Figure 5. The local thinker's information tree. 


\footnotetext{
${ }^{1}$ The Internet Appendix may be found in the online version of this article.

${ }^{2}$ In asset pricing terms, investors have a strong aversion to negative skewness in returns. Harvey and Siddique (2000) provide evidence on conditional skewness preference and asset pricing.
}

${ }^{3}$ That is, activity L is a marginal and risky investment (e.g., subprime mortgages) that intermediaries wish to undertake only after better investment opportunities (e.g., prime mortgages) are exhausted. We can think of banks as having their own broadly diversified but limited portfolios yielding the return R, as in Diamond (1984), which they can use to support safe debt without securitization. But once the potential of that portfolio to support safe debt is exhausted, banks need to find a way to use risky projects to support riskless debt. What matters for our results is not that the risky investment yields a lower average return than the safe one, but that the safe investment is in limited supply. This assumption ensures that after all safe returns are pledged to creditors, additional financing can only be raised via securitization.

${ }^{4}$ When $w^{* \text { LT }}<w^{*}$, securitization is higher under local thinking, $S_{\mathrm{L}}^{\mathrm{LT}} \geq S_{\mathrm{L}}$ for all $w$. When $w^{*, \mathrm{LT}}>w^{*}$, there might be an intermediate wealth range in which securitization is higher under rational expectations. Precisely because under rational expectations the shadow value of securitization is lower, intermediaries may need to use more of it to absorb investors' wealth.

${ }^{5}$ Our model is related to Geanakoplos (2009) in his emphasis on the pessimists financing the asset purchases of optimists with safe debt. Our approach differs from his in its focus on departures from rational expectations as opposed to differences in beliefs and in its focus on the welfare impact of securitization.

\footnotetext{
${ }^{6}$ The same effects can be obtained by having short-term debt roll over at $t=1$. We stick to long-term debt for consistency with our previous analysis. An alternative is to have all projects pay out at $t=2$ but to have some revealed to be successful at $t=1$. In this case, intermediaries revealed to be successful at $t=1$ could issue safe debt at this date to purchase claims in secondary markets. This alternative formulation would yield similar results to the current one, but requires a more cumbersome characterization of the market equilibrium at $t=1$.

${ }^{7}$ This reduction in investors' own valuation of debt is due to an unanticipated drop in $t=1$ repayment of $\left(q_{h}-\right.$ $\left.q_{l}\right) A S_{\mathrm{L}, j}^{\mathrm{LT}}$ plus a drop in $t=2$ repayment of $\left(\pi_{d}-\pi_{r}-q_{h}+q_{l}\right) A S_{\mathrm{L}, j}^{\mathrm{LT}}$.
} 
${ }^{8}$ For simplicity we assume that trading occurs before the $t=1$ debt repayment is made, so that the value of the debt includes the coupon $q_{l} A \cdot S_{\mathrm{L}, j}^{\mathrm{LT}}$.

${ }^{9}$ Rather than re-trading risky debt in secondary debt markets, a better risk allocation at $t=1$ could be achieved by additional financial innovation (tranching) at $t=1$ whereby investors carve out the risky portion of debt repayment and sell it to intermediaries while keeping the safe portion for themselves.

${ }^{10}$ Although this mechanism works though the trading of long-term debt, the same intuition can be developed in the context of riskless debt in terms of the expectation of debt rollover at $t=1$. Another possibility to implement the same equilibrium is for investors rather than intermediaries to buy the securitized pools at the outset.

${ }^{11}$ The role of CEO incentives in risk-taking by banks (Rajan (2006)) remains controversial. Fahlenbrach and Stulz (2011) and Erel, Nadauld, and Stulz (2011) do not find that bank CEOs with significant equity stakes acted more conservatively before the crisis than others. Calomiris and Mason (2003) find some evidence consistent with regulatory arbitrage in a study of credit card securitization, but also find that banks set their capital as a function of market perceptions of risk rather than maximizing the implicit subsidy from a bailout. 